\title{
Afterhyperpolarization Regulates Firing Rate in Neurons of the Suprachiasmatic Nucleus
}

\author{
Robin K. Cloues and William A. Sather \\ Department of Pharmacology, University of Colorado Health Sciences Center, Denver, Colorado 80262
}

Cluster I neurons of the suprachiasmatic nucleus (SCN), which are thought to be pacemakers supporting circadian activity, fire spontaneous action potentials that are followed by a monophasic afterhyperpolarization (AHP). Using a brain slice preparation, we have found that the AHP has a shorter duration in cells firing at higher frequency, consistent with circadian modulation of the AHP. The AHP is supported by at least three subtypes of $\mathrm{K}_{\mathrm{Ca}}$ channels, including apamin-sensitive channels, iberiotoxin-sensitive channels, and channels that are insensitive to both of these antagonists. The latter $\mathrm{K}_{\mathrm{C}}$ channel subtype is involved in rate-dependent regulation of the AHP. Voltage-clamped, whole-cell $\mathrm{Ca}^{2+}$ channel currents recorded from SCN neurons were dissected pharmacologically, revealing all of the major high-voltage activated subtypes: L-, N-, P/Q-, and R-type $\mathrm{Ca}^{2+}$ channel currents. Application of $\mathrm{Ca}^{2+}$ channel antagonists to spontaneously firing neurons indicated that predominantly L- and R-type currents trigger the AHP. Our findings suggest that apaminand iberiotoxin-insensitive $\mathrm{K}_{\mathrm{Ca}}$ channels are subject to diurnal modulation by the circadian clock and that this modulation either directly or indirectly leads to the expression of a circadian rhythm in spiking frequency.

Key words: suprachiasmatic nucleus; calcium channel; calcium-activated potassium channel; action potential; spontaneous activity; afterhyperpolarization; circadian rhythm

\section{Introduction}

The suprachiasmatic nuclei (SCN) of the hypothalamus contain the primary circadian clock that controls various physiological and behavioral rhythms in mammals, including rhythms in body temperature and sleep-wake behavior (Moore and Eichler, 1972; Klein et al., 1991). Single SCN neurons are autonomous pacemaker cells that harbor the fundamental molecular workings of the circadian clock, an interconnected set of transcriptional/ translational negative and positive feedback loops that produce coordinated, rhythmic changes in expression of clock genes (Dunlap, 1999; Reppert and Weaver, 2001). In keeping with the role of a $24 \mathrm{hr}$ pacemaker, firing of SCN neurons follows the circadian clock, with higher spike activity during the day and lower activity at night (Inouye and Kawamura, 1979; Gillette, 1991; Jagota et al., 2000). Even an isolated SCN neuron in culture, lacking any synaptic input, will sustain spontaneous and rhythmic firing (Welsh et al., 1995). Such circadian oscillation in firing frequency is known to be critical for transmittal of time information because suppression of action potentials via selective application of tetrodotoxin to the SCN abolishes the circadian rhythm of many organismal behaviors (Schwartz et al., 1987; Earnest et al., 1991; Schwartz, 1991; Newman et al., 1992). Little is known, however, regarding the mechanism that links the molecular clockworks to rhythmic electrophysiological output.

A prerequisite for understanding how the rhythm of the core of the clock is transduced into a rhythm in spike rate is the identification of ion channels responsible for spontaneous, rhythmic firing. Some of these have been identified. Thus it is known that a

Received May 22, 2002; revised Dec. 13, 2002; accepted Dec. 13, 2002.

This work was supported by National Institutes of Health Grants NS35245 and NS07083.

Correspondence should be addressed to William A. Sather, Neuroscience Center, Box B-138, University of Colorado Health Sciences Center, 4200 East Ninth Avenue, Denver, C0 80262. E-mail: william.sather@UCHSC.edu. Copyright $\odot 2003$ Society for Neuroscience $\quad 0270-6474 / 03 / 231593-12 \$ 15.00 / 0$ slowly inactivating $\mathrm{Na}^{+}$current generates an interspike depolarization that brings the membrane potential to firing threshold (Pennartz et al., 1997). Additional ion channels, including T-type $\mathrm{Ca}^{2+}$ channels, L-type $\mathrm{Ca}^{2+}$ channels, and hyperpolarizationactivated cation channels $\left(\mathrm{I}_{\mathrm{h}}\right)$, may assist in generating the interspike depolarization (Akasu et al., 1993; Jiang et al., 1995; Pennartz et al., 2002).

Other channels involved in spontaneous, rhythmic firing have remained uncharacterized. After action potential repolarization, SCN neurons exhibit an intermediate-duration afterhyperpolarization (AHP) that may contribute to regulation of firing rate. Because the AHP in other spontaneously active central neurons is a key determinant of cellular excitability (Aizenman and Linden, 1999; Bevan and Wilson, 1999) and is subject to modulation by intracellular messengers (Sah, 1996), the AHP represents a potential target for regulation by the circadian clock.

In this study, we have found that the duration of the AHP in SCN neurons firing at higher frequencies is significantly shorter than in more slowly firing neurons, consistent with circadian modulation. To better understand the nature of the changes in the AHP, we undertook a pharmacological analysis of the ion channels supporting the AHP in cluster I SCN neurons, which are the most abundant neuronal type in the SCN and are thought to be important in the output of these nuclei (Pennartz et al., 1998). This analysis classifies $\mathrm{K}_{\mathrm{Ca}}$ channels that underlie the AHP, identifies the $\mathrm{Ca}^{2+}$ channels that trigger the AHP, and highlights particular subtypes of $\mathrm{K}_{\mathrm{Ca}}$ and $\mathrm{Ca}^{2+}$ channels as candidates for circadian regulation.

\section{Materials and Methods}

Preparation of brain slices. Hypothalamic slices containing the SCN were obtained from Fisher 344 or Sprague Dawley rats (17-25 d postnatal) that had been maintained on a $12 \mathrm{hr}$ light/dark cycle for at least 1 week before they were killed. Animals were anesthetized with halothane and 
decapitated, and the brain was quickly removed and placed in ice-cold artificial CSF (ACSF) of the following composition (in mM): $126 \mathrm{NaCl}, 3$ $\mathrm{KCl}, 1.5 \mathrm{MgCl}_{2}, 2.4 \mathrm{CaCl}_{2}, 1.2 \mathrm{NaH}_{2} \mathrm{PO}_{4}, 11$ glucose, $25.9 \mathrm{NaHCO}_{3}$, continuously gassed with $95 \% \mathrm{O}_{2}-5 \% \mathrm{CO}_{2}$, $\mathrm{pH}$ 7.4. Coronal hypothalamic slices $(250 \mu \mathrm{m})$ were cut on a vibratome and incubated in ACSF at room temperature $\left(\sim 23-25^{\circ} \mathrm{C}\right)$ for at least $45 \mathrm{~min}$ before recording. Experiments were performed primarily on neurons taken from rats killed during their subjective day, although a subset of experiments was performed with neurons from subjective night rats. Recordings were made from all regions of the SCN.

Current-clamp recordings. Slices were placed in a recording chamber mounted on the stage of an upright microscope (Nikon Eclipse E600 FN). Single SCN neurons in slices were visualized using a waterimmersion objective lens [ $40 \times, 0.8$ numerical aperture (NA)], differential interference contrast optics, and a 0.9 NA condenser. An infraredsensitive video camera was used to display the field of view on a video monitor. To measure the AHP, action potential firing rate, and other properties of membrane potential changes in SCN neurons, recordings were made using the current-clamp mode of the Axopatch 200B amplifier. The bathing solution, ACSF, was bubbled continuously with $95 \%$ $\mathrm{O}_{2}-5 \% \mathrm{CO}_{2}$. Recordings were obtained at room temperature $\left(20-23^{\circ} \mathrm{C}\right)$. For $\mathrm{Co}^{2+}$ substitution experiments, a HEPES-based ACSF was used that contained (in mM): $126 \mathrm{NaCl}, 3 \mathrm{KCl}, 2.4 \mathrm{CaCl}_{2}$ (or $\mathrm{CoCl}_{2}$ ), $1.5 \mathrm{MgCl}_{2}, 26$ HEPES, 11 glucose, pH 7.4, bubbled with $100 \% \mathrm{O}_{2}$. The pipette solution contained (in $\mathrm{mm}$ ): 135 potassium gluconate, $10 \mathrm{KCl}, 10$ HEPES, 0.5 EGTA, 2 MgATP, pH 7.4. The pipette was mounted on a piezoelectric manipulator bolted onto the fixed stage of the microscope, and wholecell recordings were obtained at room temperature using an Axopatch 200B amplifier (Axon Instruments, Foster City, CA). Data were filtered at $2 \mathrm{kHz}(-3 \mathrm{~dB}$; four-pole low-pass Bessel filter integral to the Axopatch 200B amplifier) and sampled at $5 \mathrm{kHz}$ using an ITC-16 analog-to-digital converter (Instrutech, Great Neck, NY) and Pulse software (HEKA, distributed by Instrutech). In a few experiments, $10 \mathrm{~mm}$ BAPTA was substituted for EGTA. A liquid junction potential of $-12.5 \mathrm{mV}$ was measured for the solutions used in current-clamp recording (Neher, 1992); data were not adjusted for this junction potential.

For experiments examining the contribution of ryanodine receptors to the control of AHP amplitude, perforated-patch recording with amphotericin B (Sigma, St. Louis, MO) was used. The perforated-patch method was used in these experiments because it facilitated the long-duration, stable recordings that were needed to study the effects of the slowly acting, bath-applied ryanodine (Vilchis et al., 2000). A stock solution of amphotericin B (1 mg/ml, in dimethylsulfoxide) was diluted into a potassium gluconate-based pipette solution (1:200) that was otherwise identical to that used in the ruptured-patch current-clamp recordings. The patch pipette tip was filled with amphotericin B-free potassium gluconate-based solution via tip immersion, and then the pipette was back-filled with the amphotericin B-containing solution. After obtaining a high-resistance seal between pipette and cell membrane, access resistance was monitored by regular examination of the current response to a voltage step $(+10 \mathrm{mV})$. Because amphotericin B partitioned into the pipette-encircled patch, access resistance dropped within $10 \mathrm{~min}$ to a stable level of $\sim 40 \mathrm{M} \Omega$.

Voltage-clamp of $\mathrm{Ca}^{2+}$ channel currents. For recording whole-cell $\mathrm{Ba}^{2+}$ currents, the extracellular solution contained (in $\mathrm{mM}$ ): $100 \mathrm{NaCl}, 3 \mathrm{KCl}$, $0.15 \mathrm{MgCl}_{2}, 5 \mathrm{BaCl}_{2}, 17$ tetraethylammonium chloride (TEA-Cl), 0.5 4-aminopyridine, $5 \mathrm{CsCl}, 26 \mathrm{HEPES}, 10$ glucose, 0.03 bicuculline methiodide, and 0.001 tetrodotoxin, $\mathrm{pH}$ 7.4. A reservoir containing this solution was bubbled continuously with $100 \%$ oxygen, and a gravitydriven system was used to perfuse the oxygenated solution through the recording chamber at $3-5 \mathrm{ml} / \mathrm{min}$. Whole-cell recording pipettes pulled from borosilicate glass (GC120F-10; Warner Instruments, Hamden, CT) had resistances of 4-6 M $\Omega$ when filled with a solution containing (in mM): 120 TEA-Cl, 9 EGTA, 2 MgATP, and 9 HEPES, pH 7.4. After seal formation $\left(R_{\text {seal }}>3 \mathrm{G} \Omega\right)$, neurons were allowed to stabilize for $300-500$ sec before data were recorded. Series resistance compensation and capacitance transient cancellation were performed using the circuitry of the amplifier. Data were filtered at $2 \mathrm{kHz}$ and sampled at $4 \mathrm{kHz}$. Linear leak and residual capacitance currents were removed on-line by subtracting scaled and inverted current responses to hyperpolarizing voltage steps of one-quarter the amplitude of the depolarizing test pulse. A liquid junction potential of $+1.4 \mathrm{mV}$ was measured for the solutions used in voltage-clamp recording (Neher, 1992); the reported data have not been corrected for this junction potential. All experiments were performed at room temperature.

In all SCN whole-cell voltage-clamp recordings, a series resistance of typically $20-60 \mathrm{M} \Omega$ was compensated by $\sim 80 \%$. Whole-cell $\mathrm{Ba}^{2+}$ current amplitude ranged up to $\sim 300 \mathrm{pA}$, so in the well clamped compartment of the cell the maximal error in command voltage attributable to pipette series resistance was estimated as $1.2-3.6 \mathrm{mV}$ for the largest (300 pA) currents. Although SCN neurons are electrotonically compact compared with many central neurons, $\mathrm{Ba}^{2+}$ currents originating from distal processes of SCN neurons were unlikely to have been adequately clamped. An indication of this was provided by examination of the kinetics of $\mathrm{Ca}^{2+}$ channel currents. Comparison of activation and deactivation rates of whole-cell $\mathrm{Ba}^{2+}$ currents obtained from slice recordings with those recorded from dissociated SCN neurons [prepared as described by Huang (1993)] showed that activation times measured in slices $\left(\tau_{\text {act }}=2.4 \pm 0.2 \mathrm{msec} ; n=12 ;-10 \mathrm{mV}\right)$ were longer than those measured in dissociated neurons ( $\left.\tau_{\text {act }}=1.1 \pm 0.3 \mathrm{msec} ; n=5 ;-10 \mathrm{mV}\right)$. Measured deactivation times were also significantly longer in duration for slices: $\tau_{\text {deact }}=1.7 \pm 0.2 \mathrm{msec}$ in slices versus $0.4 \pm 0.3 \mathrm{msec}$ in dissociated neurons. As a consequence of the limited quality of voltage clamp in the slice recording configuration, we restricted our analysis of $\mathrm{Ca}^{2+}$ channel currents in SCN slices to peak current amplitudes: the relatively slow rates of activation and inactivation for $\mathrm{Ca}^{2+}$ channels make peak current amplitude somewhat less sensitive to clamp quality than other parameters.

Pharmacological analysis of channels. Channel antagonists used to identify $\mathrm{K}_{\mathrm{Ca}}$ channels in SCN neurons are in general highly specific (Gribkoff et al., 1997; Vergara et al., 1998; Kaczorowski and Garcia, 1999; Sah and Davies, 2000). Iberiotoxin (dose $\left.=100 \mathrm{~nm} ; \mathrm{IC}_{50}=1-5 \mathrm{~nm}\right)$ (Galvez et al., 1990; Candia et al., 1992) is a very selective blocker of type I, but not type II, $\mathrm{BK}_{\mathrm{Ca}}$ channels (Gribkoff et al., 1997; Meera et al., 2000). Apamin (dose $=100 \mathrm{~nm}$; $\left.\mathrm{IC}_{50}=0.06-1 \mathrm{~nm}\right)$ (Hughes et al., 1982; Blatz and Magleby, 1986) blocks many, but perhaps not all, neuronal $\mathrm{SK}_{\mathrm{Ca}}$ channels. Charybdotoxin (dose $=100 \mathrm{~nm}$; $\mathrm{IC}_{50}=10 \mathrm{~nm}$ ) (Anderson et al., 1988), another blocker of type I but not type II BK $\mathrm{Ca}$ channels, was tested in some experiments. Interpretation of the effects of this latter blocker was complicated by the fact that it is, in addition, a potent antagonist of some intermediate conductance $\mathrm{K}_{\mathrm{Ca}}$ channels $\left(\mathrm{IK}_{\mathrm{Ca}}\right)$ and some voltage-gated potassium channels. At the doses used for iberiotoxin and apamin, essentially complete block of sensitive channels was expected, whereas insensitive $\mathrm{K}_{\mathrm{Ca}}$ subtypes and other ion channels would not have been affected.

The stability of $\mathrm{Ca}^{2+}$ channel currents recorded from slices was advantageous for pharmacological analysis of $\mathrm{Ca}^{2+}$ channel types present in SCN neurons. During the first 300-500 sec after breakthrough, voltage-clamped $\mathrm{Ba}^{2+}$ currents carried by $\mathrm{Ca}^{2+}$ channels usually increased in amplitude and then became nearly constant; peak current amplitude diminished by only $2 \pm 0.02 \%$ over the next $420 \mathrm{sec}(n=9$ neurons). Consequently, $\mathrm{Ca}^{2+}$ channel antagonists were applied after a stabilization period of generally $300-500 \mathrm{sec}$ after the start of whole-cell recording. To achieve a steady level of block, channel blocking agents were usually applied for 180-300 sec via the bath perfusion system (3-5 $\mathrm{ml} / \mathrm{min}$ ). Delays in onset of antagonist action of up to $\sim 50 \mathrm{sec}$ were often observed, reflecting the slow solution exchange time and the time needed for antagonists to diffuse into the tissue. Considering the time needed to achieve steady block relative to the rate of run-down in peak current amplitude, run-down had only a minor effect on our measurements.

Although the $\mathrm{Ca}^{2+}$ channel antagonists used here are not ideal in their specificity, these blockers were nonetheless effective in identifying $\mathrm{Ca}^{2+}$ channel isoforms that activate the action potential AHP. The classical L channel antagonist nimodipine (dose $=10 \mu \mathrm{M} ; \mathrm{IC}_{50}=50 \mathrm{~nm}$ under our recording conditions) (Marchetti et al., 1995), the $\mathrm{N}$ channel antagonist $\omega$-conotoxin-GVIA ( $\omega$-CTx-GVIA) (dose $=3 \mu \mathrm{M}$; IC $\left._{50} \leq 0.7 \mathrm{~nm}\right)($ Boland et al., 1994), and the $\mathrm{P}$ channel antagonist $\omega$-agatoxin-IVA ( $\omega$-AgaIVA) $\left(\right.$ dose $\left.=200 \mathrm{~nm} ; \mathrm{IC}_{50}=1.5 \mathrm{~nm}\right)($ Mintz et al., 1992) were applied by 
bath perfusion at concentrations $133-4300 \times \mathrm{IC}_{50}$ values and therefore were expected to block at least $99 \%$ of current carried by these $\mathrm{Ca}^{2+}$ channel subtypes. Nonclassical L channels based on the $\mathrm{Ca}_{\mathrm{V}} 1.3\left(\alpha_{1 \mathrm{D}}\right)$ subunit may not have been fully blocked by $10 \mu \mathrm{m}$ nimodipine (Xu and Lipscombe, 2001). Q-type channels are blocked by $\omega$-Aga-IVA, but these channels are less sensitive to this antagonist, so that $\sim 70 \%$ of Q-type current was expected to be blocked at the dose used (dose $=200 \mathrm{nM}$; $\left.\mathrm{IC}_{50}=90 \mathrm{nM}\right)$ (Randall and Tsien, 1995). However, there was no significant difference between a mixture of blockers containing $\omega$-Aga-IVA and one containing $\omega$-conotoxin-MVIIC ( $\omega$-CTx-MVIIC) (dose $=3$ $\mu \mathrm{M}$ ) suggesting that the contribution of Q-type current is not large in SCN neurons. R-type current was defined as the $\mathrm{Ba}^{2+}$ current not blocked by a combination of nimodipine, $\omega$-CTx-GVIA, $\omega$-Aga-IVA, and mibefradil. We further dissected the R-type current according to block by the toxin SNX-482, which blocks $\alpha_{1 \mathrm{E}}$-based $\mathrm{Ca}^{2+}$ channels $\left(\mathrm{Ca}_{\mathrm{V}} 2.3\right.$; dose $\left.=200 \mathrm{~nm} ; \mathrm{IC}_{50}=15 \mathrm{~nm}\right)($ Newcomb et al., 1998) and the less specific blocker $\mathrm{Ni}^{2+}\left(\right.$ dose $\left.=30 \mu \mathrm{M} ; \mathrm{IC}_{50}=4-30 \mu \mathrm{M}\right)$ (Tottene et al., 1996; Zamponi et al., 1996). In this concentration range, $\mathrm{Ni}^{2+}$ would not be expected to inhibit N- or P/Q-type currents but would block a portion of L-type currents ( $\mathrm{IC}_{50}=60 \mu \mathrm{M}$ ) (Zamponi et al., 1996). $\mathrm{Ni}^{2+}$ also blocks one of the three T-type $\mathrm{Ca}^{2+}$ channel isoforms, but SCN neurons do not express the $\mathrm{Ni}^{2+}$-sensitive $\mathrm{T}$ channel isoform $\mathrm{Ca}_{\mathrm{V}} 3.3$ $\left(\alpha_{1 \mathrm{H}}\right)$ (Lee et al., 1999; Talley et al., 1999). Because of the difficulty in accurately voltage clamping SCN neurons, we did not attempt to estimate the contribution of $\mathrm{T}$ channel current in these cells. The modestly selective blocker mibefradil was included in the mixture that was used to estimate the contribution of R-type $\mathrm{Ca}^{2+}$ channels in whole-cell $\mathrm{Ba}^{2+}$ currents and to examine the contribution of $\mathrm{Ca}^{2+}$ channel subtypes to AHP activation. By using interpolated $\mathrm{IC}_{50}$ values appropriate for our recording conditions $(\sim 100-800 \mathrm{nM})$, a $500 \mathrm{~nm}$ dose of mibefradil was expected to block $38-83 \%$ of T current in SCN neurons (McDonough and Bean, 1998; Martin et al., 2000). Higher doses of mibefradil were not used because this drug interacts with other $\mathrm{Ca}^{2+}$ channel subtypes, albeit with lower potency (Bezprozvanny and Tsien, 1995; Martin et al., 2000).

Stock solutions of nimodipine, ryanodine, and picrotoxin were made by dissolving these ion channel antagonists in $100 \%$ ethanol. Stock solutions for all other ion channel antagonists were made using distilled water. Stocks were stored at $-20^{\circ} \mathrm{C}$ and in the dark. (-)-Bicuculline methiodide was not prepared as a stock solution because of its chemical instability; instead this agent was dissolved in the bath solution on a daily basis, before the start of experiments.

Channel antagonists were obtained from the following sources: picrotoxin, (-)-bicuculline methiodide, $\omega$-CTx-GVIA, apamin, iberiotoxin, charybdotoxin, and ryanodine from Sigma; $\omega$-Aga-IVA, $\omega$-CTx-MVIIC, and SNX-482 from Peptide Institute (Osaka, Japan); nimodipine from Research Biochemicals (Natick, MA); and mibefradil was a generous gift from Dr. Jean-Paul Cloze and Dr. Eric Ertel (F. Hoffmann-La Roche, Basel, Switzerland).

Mean values are reported together with their SEs, and all error bars indicate SEs of the mean. The number of experiments, $n$, indicates in all cases the number of neurons studied. Student's $t$ test was used to determine statistical significance.

\section{Results}

Spontaneous neuronal firing rate correlates with AHP duration

SCN neurons spontaneously fire action potentials over a range of frequencies $(0-15 \mathrm{~Hz})$, with average firing rates being higher during the daytime and lower during the nighttime (Inouye and Kawamura, 1979; Gillette, 1991; Jagota et al., 2000). Clock cells are not tightly synchronized with one another, however, and the circadian time at which peak firing occurs can be considerably out of phase among SCN neurons. We therefore used comparisons of action potential waveforms recorded from cells firing spontaneously at different rates, regardless of circadian time, as a strategy to identify components of the action potential that might be regulated in a circadian manner. From these comparisons, we identified an altered AHP waveform as a major factor regulating
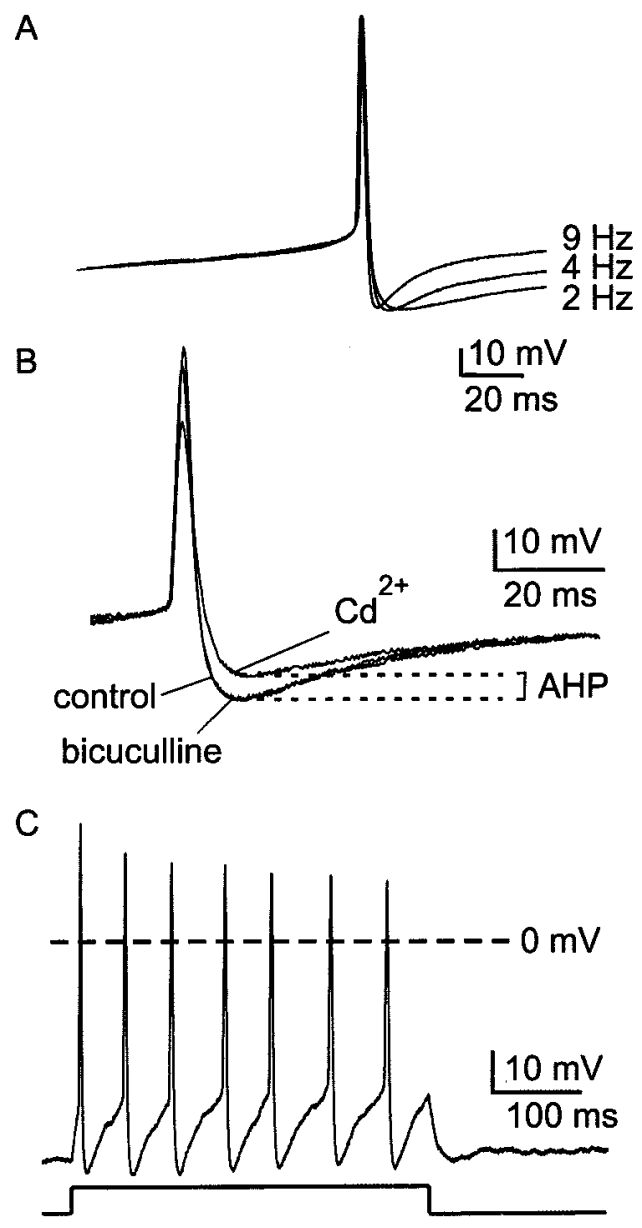

Figure 1. Firing properties of cluster ISCN neurons under whole-cell current clamp. A, Action potential waveforms, averaged from four to six spikes, from three different cells firing at the rates indicated. Note that in cells with faster firing rates, the duration of the AHP was briefer. Records of action potentials were shifted along the voltage axis to superimpose action potential threshold. $B$, Single action potentials recorded in control conditions, in the presence of $30 \mu \mathrm{m}$ bicuculline methiodide and in the presence of $30 \mu \mathrm{M} \mathrm{Cd}^{2+}$ are superimposed. $\mathrm{Cd}^{2+}$ was used as a measure of the $\mathrm{Ca}^{2+}$-dependent AHP. Bicuculline did not cause a reduction in the amplitude of the AHP. C, Positive current injection (20 pA, as indicated below current-clamp record), evoked a train of action potentials that did not exhibit spike frequency adaptation. In many, but not all neurons, there was a progressive diminution in the amplitude of action potentials that followed the initial spike.

firing frequency: the AHP became shorter in duration as spike frequency increased (Fig. $1 A$ ). In addition, the action potential width was significantly broader in slower firing neurons, but other action potential properties remained unchanged: the depolarizing ramp preceding the action potential upstroke, interspike membrane potential, action potential height, and maximum hyperpolarization after the action potential were not significantly different between fast and slow firing neurons (Table 1).

Under current-clamp conditions, action potential discharge was followed by a monophasic AHP in the majority of neurons (98 of 110) studied (Fig. 1A,B). These kinds of neurons have been classified previously as cluster I neurons (Pennartz et al., 1998). Cells with a biphasic AHP (cluster II and III neurons) were not included in our analysis. Identification of cluster I neurons was confirmed by testing for the absence of spike frequency adaptation during a train of action potentials evoked by injection of steady positive current (Fig. 1C) (Pennartz et al., 1998).

In this work, we defined AHP as the $\mathrm{Ca}^{2+}$-dependent component of the hyperpolarization that followed each action potential 
Table 1. Membrane properties of slow- and fast-firing cluster I neurons

\begin{tabular}{|c|c|c|c|c|c|c|c|c|c|c|}
\hline & \multirow{2}{*}{$\begin{array}{l}\text { Depolarizing } \\
\text { ramp } \\
\text { (mV/msec) }\end{array}$} & \multirow[b]{2}{*}{$\begin{array}{l}\text { Interspike } \\
\text { potential (mV) }\end{array}$} & \multirow{2}{*}{$\begin{array}{l}\text { Spike } \\
\text { width } \\
\text { (msec) }\end{array}$} & \multirow{2}{*}{$\begin{array}{l}\text { Spike } \\
\text { amplitude } \\
\text { (mV) }\end{array}$} & \multirow{2}{*}{$\begin{array}{l}\text { Maximum } \\
\text { hyperpolarization } \\
\text { (mV) }\end{array}$} & \multirow[b]{2}{*}{$\begin{array}{l}\text { AHP } t / 1 / 2 \\
\text { (msec) }\end{array}$} & \multicolumn{2}{|c|}{$\mathrm{Cd}^{2+}$-subtracted AHP } & \multicolumn{2}{|c|}{ IBTX-subtracted AHP } \\
\hline & & & & & & & $t_{1 / 2}(\mathrm{msec})$ & $\begin{array}{l}\text { Amplitude } \\
(\mathrm{mV})\end{array}$ & $t_{1 / 2}(\mathrm{msec})$ & $\begin{array}{l}\text { Amplitude } \\
\text { (mV) }\end{array}$ \\
\hline Number of cells $(n)$ & 9 & 9 & 9 & 9 & 9 & 9 & 6 & 6 & 5 & 5 \\
\hline Slow rate $(<3 \mathrm{~Hz})$ & $0.23 \pm 0.01$ & $-41.3 \pm 1.9$ & $4.0 \pm 0.1$ & $82.8 \pm 1.7$ & $-53.8 \pm 1.6$ & $37.3 \pm 5.0$ & $7.1 \pm 0.9$ & $11.0 \pm 3.8$ & $2.8 \pm 0.8$ & $17.4 \pm 3.3$ \\
\hline Fast rate $(>6 \mathrm{~Hz})$ & $0.25 \pm 0.03$ & $-44.7 \pm 2.3$ & $3.0 \pm 0.1$ & $77.7 \pm 3.6$ & $-58.1 \pm 2.2$ & $17.8 \pm 0.9$ & $3.1 \pm 0.4$ & $26.0 \pm 2.9$ & $3.1 \pm 0.7$ & $10.4 \pm 2.0$ \\
\hline$p$ & NS & NS & 0.0001 & NS & NS & 0.001 & 0.003 & 0.01 & NS & NS \\
\hline
\end{tabular}

Membrane properties were compared between slow $(<3 \mathrm{~Hz})$ and fast $(>6 \mathrm{~Hz})$ spontaneously firing cluster I $\mathrm{SCN}$ neurons. The depolarizing ramp was measured as the rate of voltage change $(\mathrm{mV} / \mathrm{msec}$ ) over the $50 \mathrm{msec}$ preceding action potential threshold. Interspike potential $\left(V_{\mid \mathrm{P}}\right)$ was estimated as the plateau region between action potentials. For fast-spiking neurons in which interspike plateaus were mostly brief, $V_{\mid \mathrm{P}}$ was estimated using the longer interspike intervals recorded from these irregularly firing neurons. Spike width was measured at action potential threshold. Spike amplitude was measured from $V_{\mathrm{IP}}$ to maximum depolarization. Maximum hyperpolarization reached during the AHP was measured from $0 \mathrm{mV}$. $t_{1 / 2}$ for the AHP and $\mathrm{Cd}^{2+}$-subtracted AHP was estimated as the half-decay time. For measurements of $\mathrm{Cd}^{2+}$-subtracted AHPs, slow-firing cells included those firing at $<5 \mathrm{~Hz}$. Statistical significance ( $p$ values) for differences between fast- and slow-firing neurons is indicated at the bottom of each column, with $p \geq 0.05$ considered not significant (NS).

(Fig. 1B). We measured the $\mathrm{Ca}^{2+}$-dependent component by blocking $\mathrm{Ca}^{2+}$ entry with $30 \mu \mathrm{M} \mathrm{Cd}{ }^{2+}$, which blocks virtually all $\mathrm{Ca}^{2+}$ channel current in $\mathrm{SCN}$ neurons $(93 \pm 2 \% ; n=10)$. The average difference between maximum hyperpolarization before and after $\mathrm{Cd}^{2+}$ application was $10.0 \pm 2.1 \mathrm{mV}(n=10)$. We compared this result with experiments in which external $\mathrm{Ca}^{2+}$ was replaced with $\mathrm{Co}^{2+}$. Using this method, the amplitude of the $\mathrm{Ca}^{2+}$-dependent AHP was $11.3 \pm 1.0 \mathrm{mV}(n=5)$, which was not significantly different from measurements using $\mathrm{Cd}^{2+}(p>0.1)$. We also tested the ability of a $\mathrm{Ca}^{2+}$ chelator $(10 \mathrm{~mm}$ BAPTA, included in the whole-cell patch pipette solution) to occlude the effect of $\mathrm{Cd}^{2+}$. Consistent with expectation, $\mathrm{Cd}^{2+}$ had a negligible effect on the AHP in cells loaded with BAPTA (average difference between maximum hyperpolarization before and after $\mathrm{Cd}^{2+}$ application was $2.6 \pm 0.6 \mathrm{mV} ; n=9$ ), indicating that the $\mathrm{Ca}^{2+}$-dependent AHP was abolished by high intracellular BAPTA. These results indicate that $30 \mu \mathrm{M} \mathrm{Cd}{ }^{2+}$ blocks the entry of $\mathrm{Ca}^{2+}$ required for activation of $\mathrm{K}_{\mathrm{Ca}}$ channels and that $\mathrm{Cd}^{2+}$ block provides a practical index of AHP amplitude.

In most experiments, bicuculline methiodide $(30 \mu \mathrm{M})$ or picrotoxin $(100 \mu \mathrm{M})$ was used to block $\mathrm{GABA}_{\mathrm{A}}$ receptors because SCN neurons make extensive GABAergic connections with one another (Strecker et al., 1997). Although bicuculline methiodide is known to block some kinds of $\mathrm{K}_{\mathrm{Ca}}$ channels (Khawaled et al., 1999), in the work described here, no significant reduction in AHP amplitude was observed after application of bicuculline methiodide (Fig. $1 B$ ) or picrotoxin. In the presence of bicuculline methiodide, the AHP averaged $7.8 \pm 0.4 \mathrm{mV}(n=7)$, and in the presence of picrotoxin the AHP averaged $6.7 \pm 0.8 \mathrm{mV}(n=5)$. These values were not significantly different from the AHP amplitude measured in the absence of $\mathrm{GABA}_{\mathrm{A}}$ receptor antagonists $(p>0.1)$. In reporting the results of subsequent experiments, we have therefore combined experimental results from slices treated with bicuculline methiodide, with picrotoxin, or with no $\mathrm{GABA}_{\mathrm{A}}$ receptor antagonist.

To begin probing for factors controlling AHP duration and firing frequency, we examined the effects of blocking $\mathrm{Ca}^{2+}$ influx on AHP waveform in neurons firing at different spontaneous rates (Fig. 2). In the example shown in Figure $2 \mathrm{~A}$, block of $\mathrm{Ca}^{2+}$ influx by $\mathrm{Cd}^{2+}$ had a much greater effect on the AHP in a rapidly firing neuron $(11 \mathrm{~Hz}$, right) than in a slowly firing neuron (1.3 $\mathrm{Hz}$, left). Subtraction of the action potential waveform recorded in the presence of $\mathrm{Cd}^{2+}$ from that recorded in control conditions (Fig. 2A, inset) revealed that the $\mathrm{Ca}^{2+}$-dependent AHP decayed more quickly in the faster firing neuron. Paradoxically, the $\mathrm{Ca}^{2+}$ dependent AHP was also larger in amplitude in the faster firing neuron. Among neurons firing at different spontaneous rates, the duration and amplitude of their $\mathrm{Cd}^{2+}$-subtracted AHP waveforms were highly correlated with neuronal firing rate (Fig. $2 B, C)$.
A $\quad 1.3 \mathrm{~Hz}$

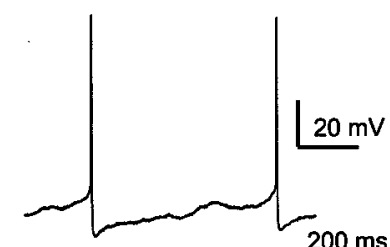

$200 \mathrm{~ms}$

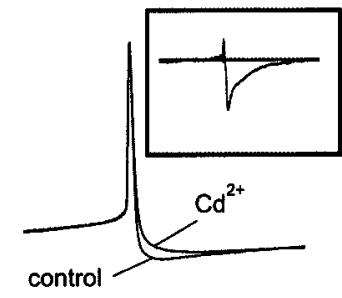

B

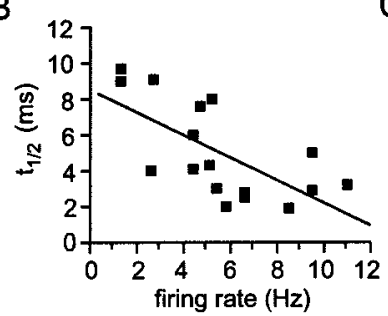

$11 \mathrm{~Hz}$
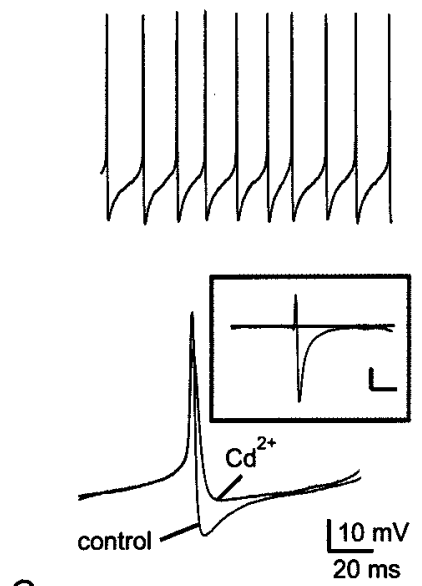

C

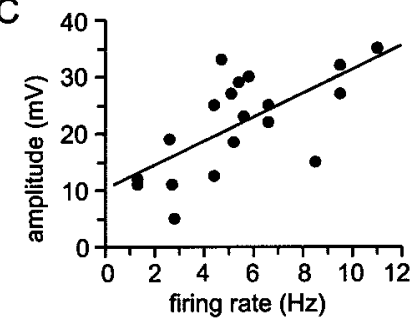

Figure 2. Changes in the $\mathrm{Ca}^{2+}$-dependent AHP over a range of firing frequencies. $A$, Comparison of two cells, one firing at $1.3 \mathrm{~Hz}$ (left panel) and one firing at $11 \mathrm{~Hz}$ (right panel). After several minutes of spontaneous firing in control conditions, $30 \mu \mathrm{M} \mathrm{Cd}^{2+}$ was applied to slices. Ensemble-averaged action potential waveforms ( $4-6$ action potentials for each condition) are shown superimposed. Insets show subtraction of waveforms recorded in $30 \mu \mathrm{M} \mathrm{Cd}^{2+}$ from control waveforms $\left(\mathrm{Cd}^{2+}\right.$-subtracted AHP). Solid line in the inset indicates $0 \mathrm{mV}$. Calibration: 10 $\mathrm{mV}, 10 \mathrm{msec}$. B, Half-time for decay of the $\mathrm{Cd}^{2+}$-subtracted AHP as a function of spontaneous firing frequency. For each neuron analyzed, decay half-time $\left(t_{1 / 2}\right)$ was measured as the time from maximum hyperpolarization to $50 \%$ of that value, and the measured $t_{1 / 2}$ value was plotted versus the spontaneous firing frequency in that particular neuron. The $t_{1 / 2}$ versus frequency data were fit with a linear regression, using a maximum likelihood estimate. Correlation coefficient was $r=-0.67$. C, Amplitude of the $\mathrm{Cd}^{2+}$-subtracted AHP as a function of spontaneous firing frequency. Amplitude of the subtracted AHP was measured from maximum hyperpolarization to $0 \mathrm{mV}$. Correlation coefficient for the regression fit was $r=0.66$.

\section{$\mathrm{Ca}^{2+}$-sensitive $\mathrm{K}^{+}$channels underlying the AHP of cluster}

\section{I neurons}

Subtype-specific antagonists were used to identify the kinds of $\mathrm{K}_{\mathrm{Ca}}$ channels that produce the AHP in cluster I SCN neurons. In this procedure, blockers of various kinds of $\mathrm{K}_{\mathrm{Ca}}$ channels were applied to spontaneously firing SCN neurons, and after establishment of a stable reduction in AHP amplitude, the AHP was com-

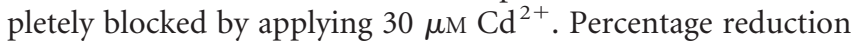
in AHP amplitude was calculated according to the equation: percentage reduction $=\left[\left(\mathrm{AHP}_{\text {control }}-\mathrm{AHP}_{\mathrm{KCa} \text {-antagonist }}\right) /\right.$ 
A
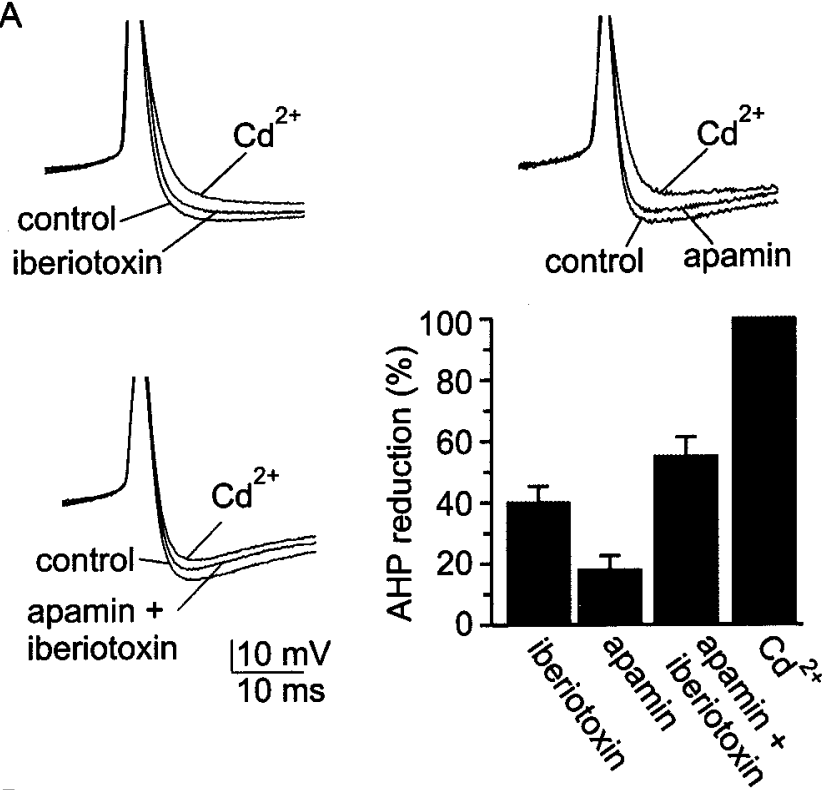

B

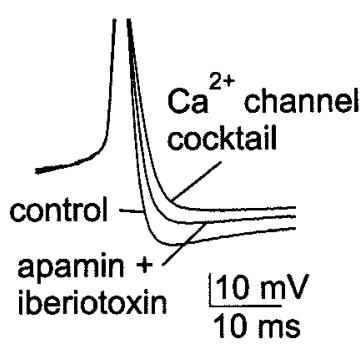

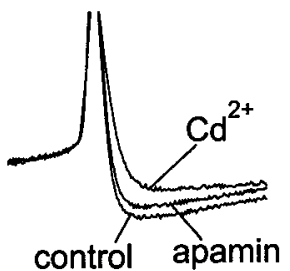

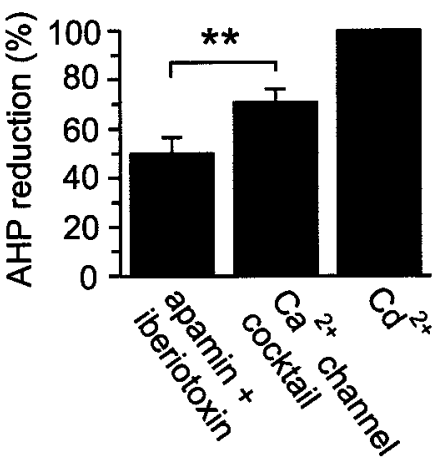

Figure 3. SCN neurons possess at least three classes of $\mathrm{K}_{\mathrm{Ca}}$ channels. $A$, Example records and group data from experiments using blockers of $\mathrm{K}_{\mathrm{Ca}}$ channels. Spontaneous action potentials were recorded under control conditions and in the presence of iberiotoxin (100 nM), apamin $(100 \mathrm{~nm})$, or both of these channel blockers. $\mathrm{Cd}^{2+}(30 \mu \mathrm{m})$ was added at the end of each experiment to fully block the $\mathrm{Ca}^{2+}$-dependent AHP, thus establishing a baseline from which to estimate the contribution to the $\mathrm{AHP}$ of $\mathrm{K}_{\mathrm{Ca}}$ channels that were sensitive to apamin, sensitive to iberiotoxin, or insensitive to both blockers. Superimposed records were always obtained from the same neuron, but each panel of records was recorded from a different neuron. Iberiotoxin reduced $A H P$ amplitude by $40 \pm 5 \%$, with a range of $18-55 \%(n=6)$; apamin reduced AHP amplitude by $18 \pm 5 \%$, with a range of $8-37 \%(n=6)$; and the combination of apamin and iberiotoxin reduced AHP amplitude by $54 \pm 10 \%$, with a range of $32-91 \%(n=5)$. B, Further diminution in the AHP by the $\mathrm{Ca}^{2+}$ channel blocker mixture after application of apamin and iberiotoxin. The $\mathrm{Ca}^{2+}$ channel mixture contained $10 \mu \mathrm{m}$ nimodipine, $3 \mu \mathrm{m} \omega$-CTx-GVIA, 200 nм $\omega$-Aga-IVA, $30 \mu \mathrm{M} \mathrm{Ni}^{2+}$, and $500 \mathrm{~nm}$ mibefradil, which will block most of the $\mathrm{Ca}^{2+}$ entry into SCN neurons (see also Fig. 5). Example action potentials in the various conditions are superimposed on the left, and a bar chart showing the percentage reduction in AHP amplitude is shown on the right. The reductions in AHP amplitude produced by the two sets of blockers (apamin + iberiotoxin, $\mathrm{Ca}^{2+}$ channel cocktail) were statistically different from one another at the $p<0.05$ level.

$\left.\left(\mathrm{AHP}_{\text {control }}-\mathrm{AHP}_{\mathrm{Cd}}\right)\right] \times 100 \%$. As shown in Figure $3 \mathrm{~A}$, iberiotoxin $(100 \mathrm{nM})$, a blocker of certain large conductance $\mathrm{K}_{\mathrm{Ca}}$ channels ( $\mathrm{BK}_{\mathrm{Ca}}$ channels), reduced AHP amplitude by $\sim 40 \%$. A peptide antagonist similar to iberiotoxin in action, charybdotoxin $(100 \mathrm{nM})$, reduced AHP amplitude by a roughly similar amount ( $28 \pm 12 \%$; range, $0-58 \% ; n=6$; data not shown). Also illustrated in Figure $3 A$ is the effect on AHP amplitude of apamin (100 nM), a blocker of certain small conductance $\mathrm{K}_{\mathrm{Ca}}$ channels ( $\mathrm{SK}_{\mathrm{Ca}}$ channels): apamin reduced AHP amplitude by $\sim 20 \%$. Coapplication of apamin and iberiotoxin reduced AHP amplitude

by only $\sim 55 \%$, suggesting that $\mathrm{SCN}$ neurons possess some $\mathrm{K}_{\mathrm{Ca}}$ channels that are insensitive to both apamin and iberiotoxin. Because $30 \mu \mathrm{M} \mathrm{Cd}^{2+}$ may also have actions on channels other than voltage-gated $\mathrm{Ca}^{2+}$ channels (Bekkers, 2000), however, we tested the prediction that block of the AHP by apamin and iberiotoxin would be smaller than block by a mixture designed to block $\mathrm{Ca}^{2+}$ channels, including L-, N-, P/Q-, R-, and T-type $\mathrm{Ca}^{2+}$ channels. Figure $3 B$ shows that the $\mathrm{Ca}^{2+}$ channel mixture further reduced AHP amplitude after application of the combination of apamin and iberiotoxin, consistent with the idea that the AHP of SCN neurons is supported by at least three subtypes of $\mathrm{K}_{\mathrm{Ca}}$ channels: apamin-sensitive channels, iberiotoxin-sensitive channels, and channels insensitive to both antagonists. In addition, the wide range in percentage block by iberiotoxin or apamin suggests that there is considerable cell-to-cell variability in the expression of $\mathrm{K}_{\mathrm{Ca}}$ channels (Fig. 3, legend).

We examined whether the iberiotoxin-sensitive portion of the AHP changed with firing frequency, as observed for the $\mathrm{Cd}^{2+}$. subtracted AHP (Fig. 2). When we applied $100 \mathrm{~nm}$ iberiotoxin to SCN neurons firing spontaneously between 0.2 and $8.2 \mathrm{~Hz}(n=$ 16) and measured the amplitude and decay kinetics of the iberiotoxin-subtracted potential, we found no correlation between firing rate and either decay half-time (correlation coefficient $r=0.08$; Table 1$)$ or amplitude $(r=-0.25)$.

\section{$\mathrm{Ca}^{2+}$ channel subtypes present in neurons of the SCN}

Subtypes of $\mathrm{Ca}^{2+}$ channels present in SCN neurons were identified using antagonists effective against particular $\mathrm{Ca}^{2+}$ channel subtypes. In these voltage-clamp experiments, $\mathrm{Ba}^{2+}$ was substituted for $\mathrm{Ca}^{2+}$ as the permeant ion to suppress $\mathrm{Ca}^{2+}$-sensitive currents. Figure $4 A-D$ illustrates the action of subtype-selective $\mathrm{Ca}^{2+}$ channel antagonists on whole-cell $\mathrm{Ba}^{2+}$ current recorded from voltage-clamped SCN neurons in hypothalamic slices. As shown in Figure $4 A$, the $\mathrm{L}$ channel antagonist nimodipine partially blocked $\mathrm{Ba}^{2+}$ current, indicating that L-type $\mathrm{Ca}^{2+}$ channels carried a fraction of whole-cell $\mathrm{Ca}^{2+}$ channel current. For a series of control neurons, total $\mathrm{Ba}^{2+}$ current remained stable over the typical duration of experiments (5-15 $\mathrm{min}$ ), as shown by the data points and dashed line in Figure $4 A$. N-type and P/Q-type $\mathrm{Ca}^{2+}$ channels were also identified in SCN neurons, on the basis of partial block of whole-cell $\mathrm{Ba}^{2+}$ current by high concentrations of $\omega$-CTx-GVIA and $\omega$-Aga-IVA (Fig. $4 B, C$ ).

Figure $4 D$ shows that application of a combination of antagonists designed to block L-, N-, P/Q-, and T-type channels (10 $\mu \mathrm{M}$ nimodipine, $3 \mu \mathrm{M} \omega$-CTX-GVIA, $200 \mathrm{~nm} \omega$-Aga-IVA, and 500 nM mibefradil) blocked only half of the total $\mathrm{Ba}^{2+}$ current in an $\mathrm{SCN}$ neuron. At the antagonist concentrations used, classical L-, $\mathrm{N}$-, and P-type channels were expected to be fully blocked. Approximately $70 \%$ of any Q-type current present was expected to have been blocked by $200 \mathrm{~nm} \omega$-Aga-IVA. We tested whether the current remaining in the presence of L-, N-, P-, and T-type channel blockers was carried by Q-type channels by substituting $\omega$-CTx-MVIIC ( $3 \mu \mathrm{M})$ for $\omega$-Aga-IVA in the mixture. This concentration of $\omega$-CTx-MVIIC would be expected to fully block both $\mathrm{P}$ - and Q-type $\mathrm{Ca}^{2+}$ channels over the time that it was applied (>10 min) (Randall and Tsien, 1995). We found that the mixture containing $\omega$-CTx-MVIIC did not block significantly more $\mathrm{Ba}^{2+}$ current $(52 \pm 6 \% ; n=4)$ than the mixture containing $\omega$-Aga-IVA $(51 \pm 4 \% ; n=12 ; p>0.1)$. Thus, most of the current resistant to block by the combination of nimodipine, $\omega$-CTxGVIA, $\omega$-Aga-IVA (or $\omega$-CTx-MVIIC), and mibefradil was, by definition, R type (Zhang et al., 1993; Randall and Tsien, 1995).

In some neuronal cell types, R-type current is carried, at least 
in part, by $\alpha_{1 \mathrm{E}}$-based $\mathrm{Ca}^{2+}$ channels (Wang et al., 1999; Foehring et al., 2000; Tottene et al., 2000; Lee et al., 2002). We therefore tested the effect of SNX-482, a toxin selective for $\alpha_{1 \mathrm{E}}$-based $\mathrm{Ca}^{2+}$ channels, on whole-cell $\mathrm{Ba}^{2+}$ current. Figure $5 \mathrm{~A}$ illustrates a cell in which a large portion of $\mathrm{Ba}^{2+}$ current $(77 \%)$ was blocked by a combination of nimodipine, $\omega$-CTxGVIA, $\omega$-Aga-IVA, and mibefradil. The remaining current was not affected by application of SNX-482 (200 nM) but could be blocked by addition of $\mathrm{Cd}^{2+}(30 \mu \mathrm{M})$, a nonselective blocker of all voltage-gated $\mathrm{Ca}^{2+}$ channel subtypes. In seven cells tested, SNX- 482 blocked $<10 \%$ of current remaining in the presence of $\mathrm{L}-, \mathrm{N}$-, $\mathrm{P} / \mathrm{Q}-$, and T-type channel blockers, suggesting that $\alpha_{1 \mathrm{E}}$-based $\mathrm{Ca}^{2+}$ channels are not significantly expressed in SCN neurons.

R-type current can also be blocked with some selectivity (see Materials and Methods) by the divalent cation $\mathrm{Ni}^{2+}$ (Zamponi et al., 1996; N'Gouemo and Rittenhouse, 2000; Tottene et al., 2000), and so we tested $\mathrm{Ni}^{2+}$ on the current resistant to block by the combination of nimodipine, $\omega$-CTx-GVIA, $\omega$-Aga-IVA, and mibefradil. As illustrated in Figure $5 B, \mathrm{Ni}^{2+}(30 \mu \mathrm{M})$ blocked $\sim 75 \%$ of the resistant $\mathrm{Ba}^{2+}$ current, confirming the identification of R-type current in these neurons. In the presence of nimodipine, $\omega$-CTx-GVIA, $\omega$-Aga-IVA, and mibefradil, $\mathrm{Ni}^{2+}$ blocked $40 \pm 6 \%(n=7)$ of the original total $\mathrm{Ba}^{2+}$ current, a percentage not significantly different from $\mathrm{Ni}^{2+}$ block in the absence of the other four $\mathrm{Ca}^{2+}$ channel antagonists $(45 \pm 6 \% ; n=6 ; p>0.1)$. This observation suggests that $30 \mu \mathrm{M} \mathrm{Ni}^{2+}$ does not block $\mathrm{Ca}^{2+}$ currents other than R type in SCN neurons. A summary of the $\mathrm{Ca}^{2+}$ channel antagonist data is illustrated in Figure $5 C$.

\section{Effect of $\mathrm{Ca}^{2+}$ channel blockers on the AHP}

In some neurons, tight coupling exists between specific classes of $\mathrm{Ca}^{2+}$ channels and $\mathrm{K}_{\mathrm{Ca}}$ channels (Davies et al., 1996; Marrion and Tavalin, 1998; Pineda et al., 1998). We therefore tested the effect of individual $\mathrm{Ca}^{2+}$ channel antagonists on the AHP amplitude in spontaneously firing SCN neurons (Fig. 6). The N-, P/Q-, and T-type $\mathrm{Ca}^{2+}$ channel blockers $\omega$-CTx-GVIA $(3 \mu \mathrm{M}), \omega$-AgaIVA (200 nM), and mibefradil (500 nM) had few or negligible effects on AHP amplitude ( $<10 \% ; n=6$ for each), suggesting minimal participation of these kinds of channels in activating the AHP. In contrast, the L-type $\mathrm{Ca}^{2+}$ channel antagonist nimodipine $(10 \mu \mathrm{M})$ had a significant effect on peak AHP, reducing the amplitude by $\sim 30 \%$.

We also tested whether R-type current was involved in triggering the AHP (Fig. 7A,B). A combination of antagonists that block non-R-type $\mathrm{Ca}^{2+}$ current (nimodipine, $\omega$-CTx-GVIA, $\omega$-Aga-IVA, and mibefradil) only partially suppressed the AHP (46 $\pm 5 \% ; n=5$ ), suggesting that $\mathrm{R}$-type current activated $\mathrm{K}_{\mathrm{Ca}}$ channels responsible for the remainder of the AHP. Indeed, block of $\mathrm{R}$ current by $\mathrm{Ni}^{2+}(30 \mu \mathrm{M})$ partially suppressed the AHP
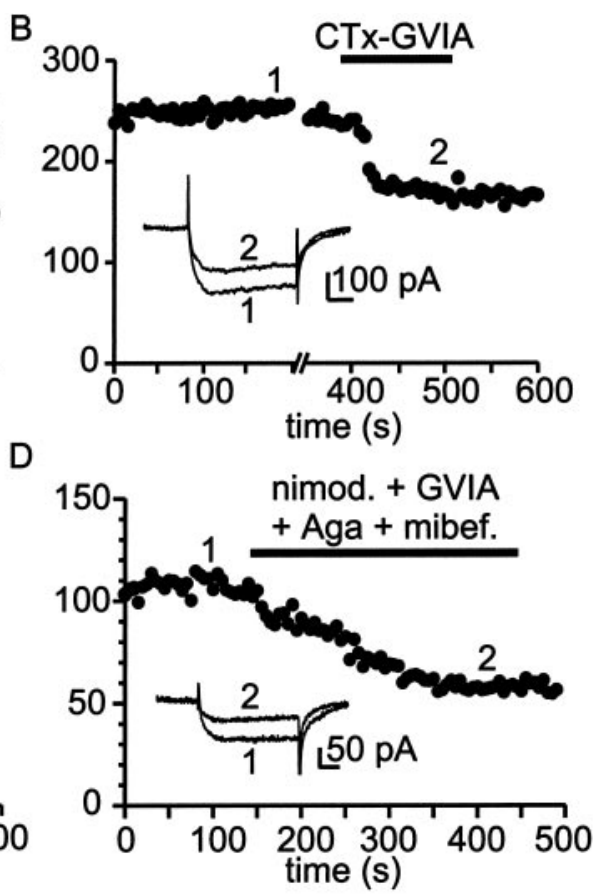

Figure 4. Pharmacological identification of $\mathrm{Ca}^{2+}$ channel currents in $\mathrm{SCN}$ neurons. $A$, Plot of peak inward Ba ${ }^{2+}$ current versus ime for a single $S C N$ neuron recorded in a hypothalamic slice. The $L$ channel antagonist nimodipine $(10 \mu \mathrm{m})$ was applied during the 列 rominent component of antagonist-resistant current (R-type $\mathrm{Ca}^{2+}$ current). In all examples currents were activated every $5 \mathrm{sec}$ by 50 msec voltage steps from -80 to $-10 \mathrm{mV}$ (voltage at which peak inward current was obtained).

( $\sim 20 \%)$. Coapplication of the L- and R-type blockers nimodipine and $\mathrm{Ni}^{2+}$ had effects that were additive, reducing the AHP by $\sim 50 \%$. This block was not significantly different from that produced by application of a mixture containing all $\mathrm{Ca}^{2+}$ channel blockers (nimodipine, $\omega$-CTx-GVIA, $\omega$-Aga-IVA, mibefradil, $\left.\mathrm{Ni}^{2+} ; 63 \% \pm 5 \% ; n=7 ; p>0.1\right)$.

Because $\mathrm{Ca}^{2+}$ release via ryanodine receptors triggers the AHP in some kinds of neurons, we tested the effect of ryanodine, an inhibitor of $\mathrm{Ca}^{2+}$-induced $\mathrm{Ca}^{2+}$ release (Sutko et al., 1985; Akita and Kuba, 2000), on the AHP of cluster I SCN neurons (Fig. $7 C)$. Measured from spike threshold, maximum hyperpolarization after a spike was diminished by $1.4 \pm 0.5 \mathrm{mV}(n=4)$ after 30 min of exposure to $10 \mu \mathrm{M}$ ryanodine. This was not statistically different from the reduction in afterhyperpolarization magnitude observed after $30 \mathrm{~min}$ in control conditions $(1.4 \pm 1.0 \mathrm{mV}$; $n=3)$. Thus release of $\mathrm{Ca}^{2+}$ from ryanodine-sensitive stores appears to play a minimal or no role in generating the AHP in cluster I SCN neurons, despite the importance of ryanodine receptors in mediating light-induced phase delays in the SCN (Ding et al., 1998).

\section{Effects on firing rate resulting from pharmacological} antagonism of the AHP

In many kinds of neurons, the magnitude and duration of the AHP are important factors in setting interspike interval and, thereby, neuronal firing rate. For example, reduction in the AHP by the action of neurotransmitters can increase firing rate (Madison and Nicoll, 1982; Pedarzani and Storm, 1995). The relation- 

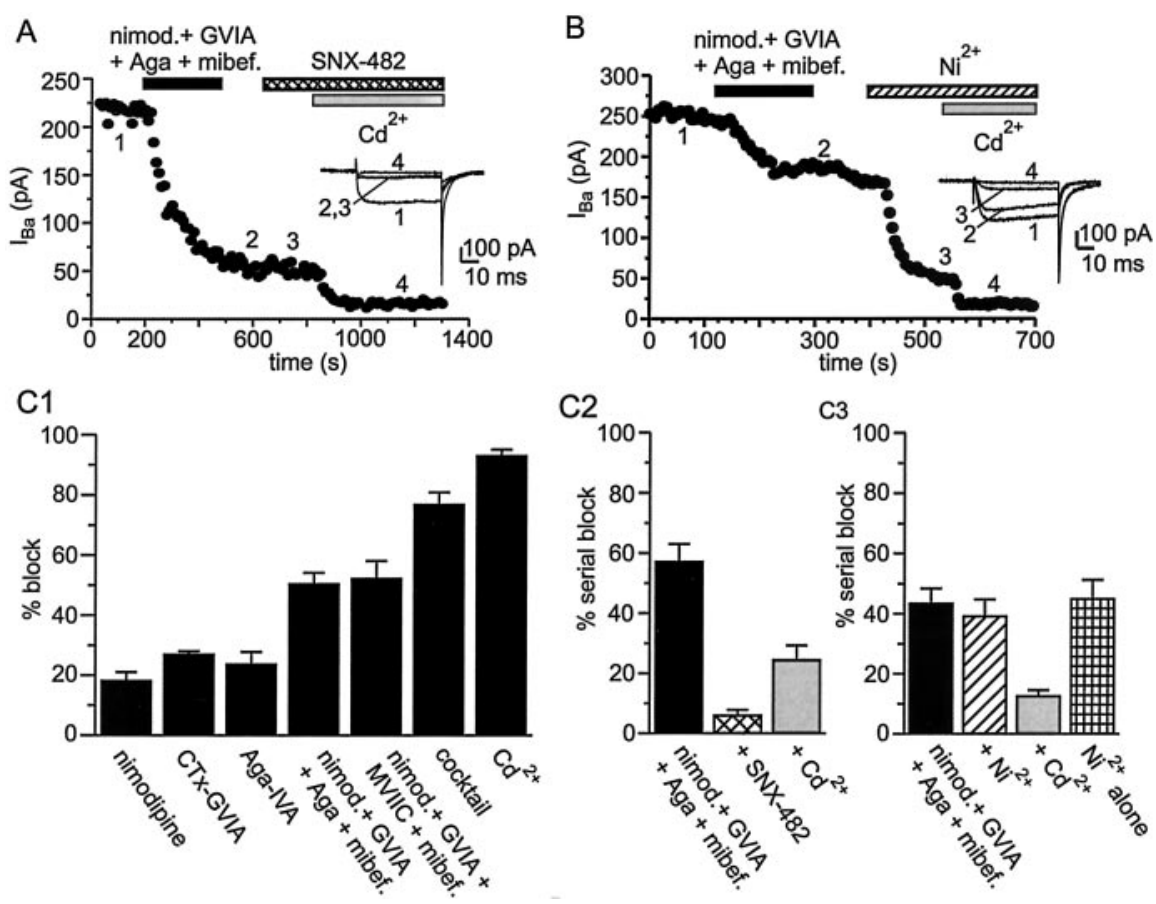

C3

Figure 5. SCN neurons possess a large R-type $\mathrm{Ca}^{2+}$ current. $A$, Plot of peak inward $\mathrm{Ba}^{2+}$ current versus time for an experiment designed to test the sensitivity of R-type $\mathrm{Ca}^{2+}$ current to the $\alpha_{1 \mathrm{E}}$ channel blocker SNX-482. A combination of nimodipine (10 $\left.\mu \mathrm{M}\right)$, $\omega$-CTx-GVIA (3 $\mu \mathrm{M}), \omega$-Aga-IVA (200 nm), and mibefradil (500 nm) was added to block L-, N-, P/Q-, and T-type Ca ${ }^{2+}$ channels. After a washout period, SNX-482 (200 nm) was applied but had no effect on the current. At the end of the experiment, complete block of $\mathrm{Ca}^{2+}$ channels was produced by applying $30 \mu \mathrm{m} \mathrm{Cd}^{2+}$. Example records obtained at various times during the experiment are illustrated in the inset. $B$, In a similar experiment, the R current antagonist $\mathrm{Ni}^{2+}(30 \mu \mathrm{m})$ was applied, which blocked $75 \%$ of the current remaining after application of blockers of L-, N-, P/Q-, and T-type channels. C, Summary of average percentage block by $\mathrm{Ca}^{2+}$ channel antagonists (same concentrations as described in $A$ ). In (1, the various antagonists were applied either alone or in various combinations. As a percentage of total $\mathrm{Ba}^{2+}$ current, nimodipine blocked $18 \pm 3 \%$, with a range of $0-33 \%(n=18)$; $\omega$-CTx-GVIA blocked $27 \pm 1 \%$, with a range of $24-30 \%(n=6) ; \omega$-Aga-IVA blocked $24 \pm 4 \%$, with a range of $15-47 \%(n=$ 8). Combined application of nimodipine, $\omega$-CTx-GVIA, $\omega$-Aga-IVA, and mibefradil blocked $51 \pm 4 \%$, with a range of 31-77\% $(n=12)$; substitution of $\omega$-Aga-IVA with $\omega$-CTx-MVIIC ( $3 \mu \mathrm{m})$ blocked $52 \pm 6 \%$, with a range of $36-62 \%(n=4)$. Combined application of nimodipine, $\omega$-CTx-GVIA, $\omega$-Aga-IVA, mibefradil, and $\mathrm{Ni}^{2+}$ (cocktail) blocked $76 \pm 4 \%(n=6)$ of total $\mathrm{Ba}^{2+}$ current. At $30 \mu \mathrm{m}, \mathrm{Cd}^{2+}$ applied alone blocked $93 \pm 2 \%(n=10)$ of total $\mathrm{Ba}^{2+}$ current in SCN neurons. In $C_{2}$, nimodipine, $\omega$-CTx-GVIA, $\omega$-Aga-IVA, and mibefradil were applied together to neurons first, followed by SNX-482 and then $\mathrm{Cd}^{2+}$. The combination of nimodipine, $\omega$-CTx-GVIA, $\omega$-Aga-IVA, and mibefradil blocked $57 \pm 6 \%$, with a range of $44-77 \%(n=6)$ of total $\mathrm{Ba}^{2+}$ current. After application of this combination of blockers, addition of SNX-482 blocked only $6 \pm 2 \%(n=6)$ of total Ba ${ }^{2+}$ current, and subsequent application of $30 \mu \mathrm{M} \mathrm{Cd}^{2+}$ blocked the remaining current $(25 \pm 5 \% ; n=6)$. In $(3$, the experiment was conducted in an identical manner, with the exception that application of the L-, $\mathrm{N}-, \mathrm{P} / \mathrm{Q}-$, and T-type blockers was followed by $\mathrm{Ni}^{2+}$ and then $\mathrm{Cd}^{2+}$. The combination of nimodipine, $\omega$-CTx-GVIA, $\omega$-Aga-IVA, and mibefradil blocked $44 \pm 7 \%$, with a range of $31-50 \%(n=6)$ of total $\mathrm{Ba}^{2+}$ current. After application of this combination of blockers, addition of $\mathrm{Ni}^{2+}$ blocked $52 \pm 3 \%(n=$

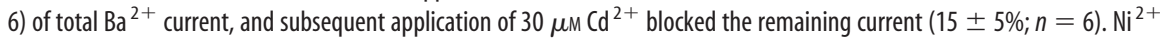
added alone to SCN neurons blocked $45 \pm 6 \%$, with a range of $29-66 \%(n=6)$.

ship between firing frequency of SCN neurons and duration of the $\mathrm{Ca}^{2+}$-dependent AHP (Fig. $2 \mathrm{~B}$ ) predicts that reducing AHP duration would increase firing rate. We therefore examined how pharmacological antagonism of the AHP affected spike frequency in spontaneously active cluster I SCN neurons (Fig. $8 \mathrm{~A}$ ). In these experiments, $\mathrm{Ca}^{2+}$ channel blockers and $\mathrm{K}_{\mathrm{Ca}}$ channel blockers were tested. Slices were bathed in bicuculline methiodide $(30 \mu \mathrm{M})$ or picrotoxin $(100 \mu \mathrm{M})$ to preclude secondary effects of $\mathrm{Ca}^{2+}$ or $\mathrm{K}_{\mathrm{Ca}}$ channel blockers on firing rate, effects that could otherwise have arisen via alteration of $\mathrm{Ca}^{2+}$-dependent release of GABA. In control experiments, spontaneous firing rates were found to be stable during the initial $15 \mathrm{~min}$ after breakthrough, and we therefore confined our measurements to this time period.

$\mathrm{K}_{\mathrm{Ca}}$ channel antagonists did not alter firing rate. Neither block of $\mathrm{SK}_{\mathrm{Ca}}$ channels by apamin $(100 \mathrm{nM})$ nor block of $\mathrm{BK}_{\mathrm{Ca}}$ channels by iberiotoxin (100 nM) had a statistically significant effect on spike frequency (Fig. $8 B$ ), nor did individual subtype-selective blockers of $\mathrm{Ca}^{2+}$ channel subtypes alter firing rate. Applied alone, nimodipine, $\omega$-CTx-GVIA, $\omega$-Aga-IVA, mibefradil, or $\mathrm{Ni}^{2+}$ did not significantly affect firing rate (Fig. $8 \mathrm{~B}$ ). However, application of a combination of nimodipine plus $\mathrm{Ni}^{2+}$ had a significant effect on firing rate $(p<0.01$; $n=6$ ), although the effect was, unexpectedly, a decrease in rate. Simultaneous application of all five subtype-selective $\mathrm{Ca}^{2+}$ channel blockers also slowed firing rate $(p<0.01 ; n=7)$. In contrast, complete blockade of $\mathrm{Ca}^{2+}$ entry by $\mathrm{Cd}^{2+}(30 \mu \mathrm{M})$ increased firing rate $\sim 1.5$-fold (see Discussion).

\section{Effects of channel blockers on spike parameters}

Blockers of $\mathrm{Ca}^{2+}$ channels and $\mathrm{K}_{\mathrm{Ca}}$ channels were examined for their effects on spike parameters other than the AHP: interspike potential $\left(V_{\mathrm{IP}}\right)$, determined as the plateau region of membrane potential between action potentials; spike amplitude, measured from $V_{\text {IP }}$ to peak depolarization; and spike width, measured at half amplitude. None of the blockers tested significantly affected $V_{\mathrm{IP}}$, indicating that changes in firing rate could not be attributed to changes in $V_{\text {IP }}$ (Table 2). This was confirmed for $\mathrm{Cd}^{2+}$ by the fact that membrane potential was not affected when this blocker was applied, whereas spiking was suppressed by tetrodotoxin $(1 \mu \mathrm{M}): V_{\text {IP }}$ was $-40 \pm 3.1 \mathrm{mV}$ before $\mathrm{Cd}^{2+}$ application and $-39 \pm 2.4 \mathrm{mV}$ during $\mathrm{Cd}^{2+}$ treatment $(p>0.1 ; n=6)$.

Action potential amplitude was not affected by $\mathrm{K}_{\mathrm{Ca}}$ channel blockers nor by $\mathrm{Ca}^{2+}$ channel blockers except for $\mathrm{Cd}^{2+}$, which substantially attenuated spike height (Table 2). A possible explanation for the $\mathrm{Cd}^{2+}$ effect is that block of the AHP, complete for $\mathrm{Cd}^{2+}$ but only partial for the other blockers (even the $\mathrm{Ca}^{2+}$ channel blocker mixture) (Fig. 7), prevented normal recovery from inactivation of voltagegated $\mathrm{Na}^{+}$channels. In contrast to $V_{\text {IP }}$ and spike amplitude, spike width was more sensitive to blockers (Table 2). Action potentials were broadened by the $\mathrm{BK}_{\mathrm{Ca}}$ channel blocker iberiotoxin, consistent with the known role of $\mathrm{BK}_{\mathrm{Ca}}$ channels in action potential repolarization. Action potentials were also broadened by the $\mathrm{N}$-channel blocker $\omega$-CTx-GVIA, by the five-component $\mathrm{Ca}^{2+}$ channel blocker mixture (nimodipine, $\omega$-CTx-GVIA, $\omega$-AgaIVA, $\mathrm{Ni}^{2+}$, and mibefradil), and by the nonselective $\mathrm{Ca}^{2+}$ channel blocker, $\mathrm{Cd}^{2+}$, presumably because $\mathrm{BK}_{\mathrm{Ca}}$ channel activity was reduced consequent to $\mathrm{Ca}^{2+}$ channel block.

\section{Discussion}

Firing frequency of neurons is commonly modulated by spike afterhyperpolarizations (Barrett and Barrett, 1976; Yarom et al., 


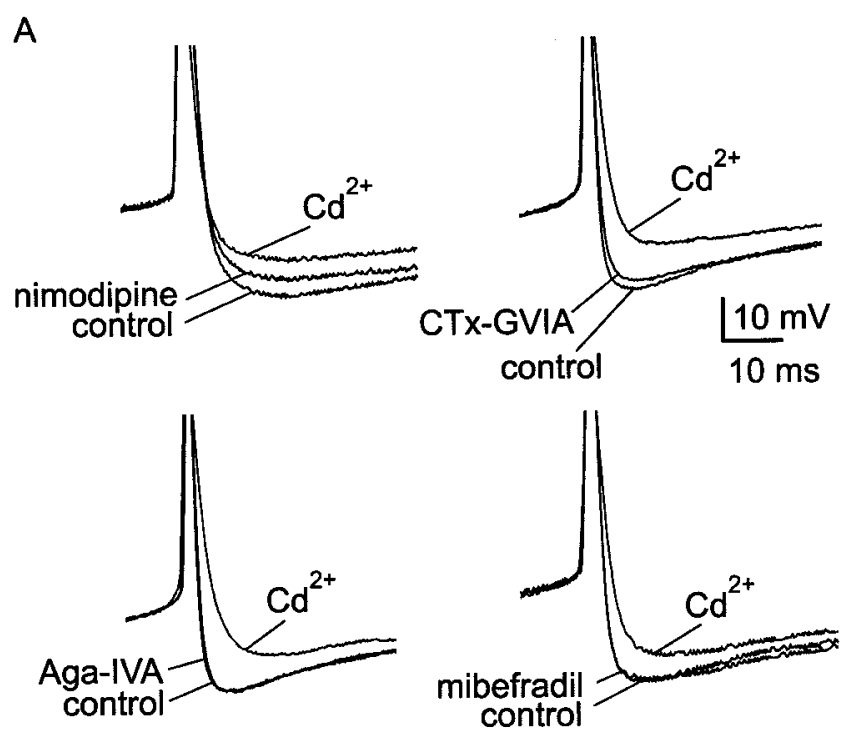

B

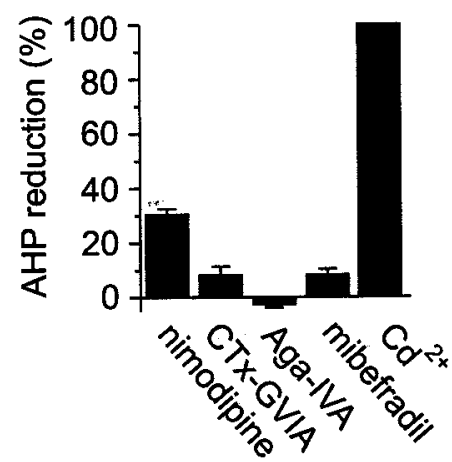

Figure 6. Action of $\mathrm{Ca}^{2+}$ channel blockers on AHP amplitude. $A, \mathrm{Ca}^{2+}$ channel antagonists were applied to spontaneously firing neurons in $\mathrm{SCN}$ slices. Examples from individual experiments are shown, superimposing three records from each experiment (control, block by an isoform-specific antagonist, and block by $\left(d^{2+}\right) . B$, A summary of the results from these experiments is presented as a bar chart. Doses used for individual antagonists were $10 \mu \mathrm{m}$ nimodipine, $3 \mu \mathrm{m} \omega$-CTx-GVIA, $200 \mathrm{~nm} \omega$-Aga-IVA, and $500 \mathrm{~nm}$ mibefradil. Nimodipine reduced AHP amplitude by $31 \pm 2 \%$, with a range of $17-51 \%(n=6)$; the blockers $\omega$-CTx-GVIA, $\omega$-AgaIVA, and mibefradil reduced AHP amplitude by $<10 \%$ ( $n=6$ for each).

1985; Madison and Nicoll, 1986; Sah, 1996). For SCN neurons, in which rhythmic modulation of firing communicates circadian information to the organism, the role of the AHP in modulating spike rate has previously received little attention. Here we have focused on cluster I neurons of the SCN, which are the most abundant cells present in SCN (Pennartz et al., 1998) and exhibit rhythmic modulation of firing frequency (Welsh et al., 1995). Our examination of action potential waveforms from cluster I neurons firing at different rates revealed that the AHP duration shortens as spike frequency increases.

Three classes of $\mathrm{K}_{\mathrm{Ca}}$ channels in SCN neurons

Evidence that $\mathrm{K}_{\mathrm{Ca}}$ channels regulate rhythmic firing of SCN neurons has been sparse. Injection of apamin into brain ventricles has been found to disrupt normal circadian behaviors (Gandolfo et al., 1996), and charybdotoxin and apamin block serotonininduced phase shifting of SCN firing (Prosser et al., 1994). Our pharmacological dissection of $\mathrm{K}_{\mathrm{Ca}}$ channel current shows that cluster I neurons express three major groups of $\mathrm{K}_{\mathrm{Ca}}$ channels. $\mathrm{SK}_{\mathrm{Ca}}$ and $\mathrm{BK}_{\mathrm{Ca}}$ channels were identified on the basis of partial block of the AHP by apamin and iberiotoxin. Apamin selectively
A
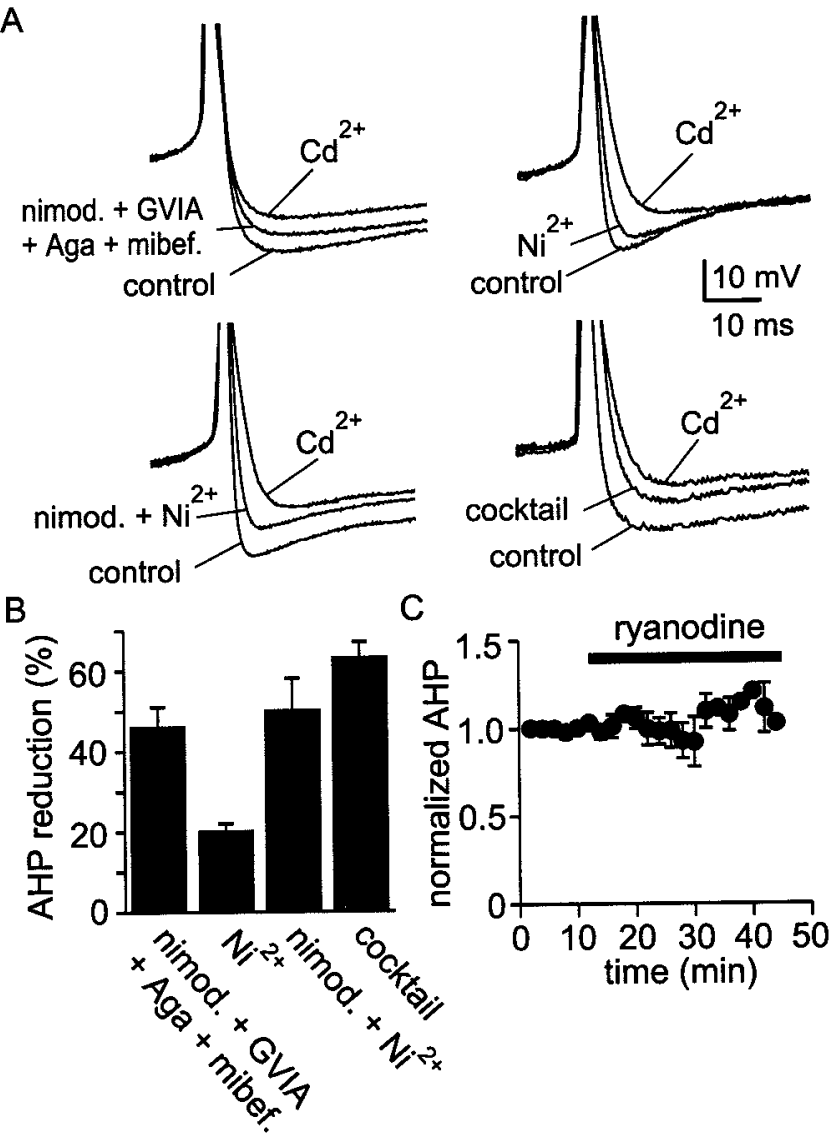

Figure 7. Participation of R-type current in AHP activation. A, Coapplication of antagonists for $\mathrm{L}-, \mathrm{N}-, \mathrm{P} / \mathrm{Q}-$, and T-type $\mathrm{Ca}^{2+}$ channels blocked $\sim 50 \%$ of the AHP, suggesting that R-type $\mathrm{Ca}^{2+}$ channels must also participate in activation of $\mathrm{K}_{\mathrm{Ca}}$ channels. Application of $\mathrm{Ni}^{2+}(30 \mu \mathrm{m})$ reduced AHP amplitude and was additive with nimodipine (10 $\mu \mathrm{m})$. A mixture of antagonists that included nimodipine, $\omega$-CTx-GVIA, $\omega$-Aga-IVA, mibefradil, and $\mathrm{Ni}^{2+}$ blocked the AHP by a similar amount as $\mathrm{Ni}^{2+}$ and nimodipine applied together. $B$, Summary of AHP reduction by combinations of $\mathrm{Ca}^{2+}$ channel blockers. A combination of nimodipine (10 $\left.\mu \mathrm{M}\right), \omega$-CTX-GVIA (3 $\mu \mathrm{M}), \omega$-Aga-IVA ( $200 \mathrm{~nm})$, and mibefradil $(500 \mathrm{~nm})$ inhibited the AHP by $46 \pm 5 \%$, with a range of $31-56 \%(n=5) . \mathrm{Ni}^{2+}$ added alone $(30 \mu \mathrm{m})$ reduced $\mathrm{AHP}$ amplitude by $20 \pm 2 \%$, with a range of $10-25 \%(n=6)$. Inhibition of the AHP by coapplication of nimodipine plus $\mathrm{Ni}^{2+}$ (50 $\pm 8 \%$; range, $17-90 \% ; n=8$ ) was comparable with application of a mixture containing nimodipine, $\omega$-CTx-GVIA, $\omega$-Aga-IVA, mibefradil, and $\mathrm{Ni}^{2+}$ (63 $\pm 5 \%$; range, $49-78 \% ; n=$ 7). C, Plot of normalized AHP amplitude versus time for four cells in which ryanodine (10 $\mu \mathrm{m}), \mathrm{a}$ blocker of $\mathrm{Ca}^{2+}$-induced $\mathrm{Ca}^{2+}$ release, was applied for $>30 \mathrm{~min}$. Long-term recordings were made using the perforated-patch method to prevent rundown of the AHP.

blocks SK2 and SK3 subtypes of $\mathrm{SK}_{\mathrm{Ca}}$ channels, whereas iberiotoxin selectively blocks type I $\mathrm{BK}_{\mathrm{Ca}}$ channels. Coapplication of nearly saturating concentrations of apamin and iberiotoxin reduced the amplitude of the AHP by only 55\%, however, indicating that a large fraction of the channels underlying the AHP are insensitive to these blockers. SK1-based channels, which under some conditions have been found to be insensitive to apamin and iberiotoxin (Kohler et al., 1996; Sah, 1996; Vergara et al., 1998; Kaczorowski and Garcia, 1999; Sah and Davies, 2000), are not expressed in SCN neurons (Stocker and Pedarzani, 2000). Other channels that might support the apamin- and iberiotoxininsensitive $\mathrm{K}_{\mathrm{Ca}}$ channel current in SCN neurons include iberiotoxininsensitive $\mathrm{BK}_{\mathrm{Ca}}$ channels (Meera et al., 2000), intermediate conductance $\mathrm{IK}_{\mathrm{Ca}}$ channels, or the essentially uncharacterized channels that underlie the apamin- and iberiotoxin-insensitive slow afterhyperpolarization in hippocampal pyramidal neurons $\left(\mathrm{I}_{\text {sAHP }}\right)$ (Sah and Faber, 2002). 
A control

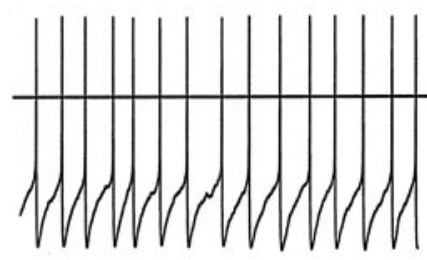

$\mathrm{Ca}^{2+}$ channel cocktail

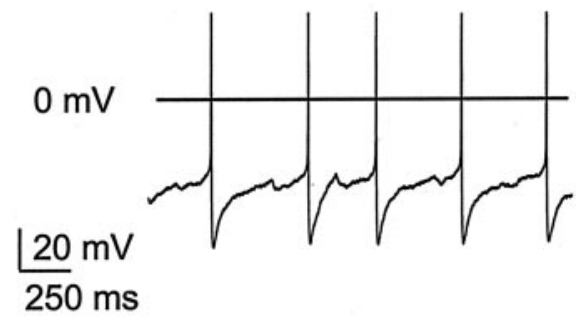

B

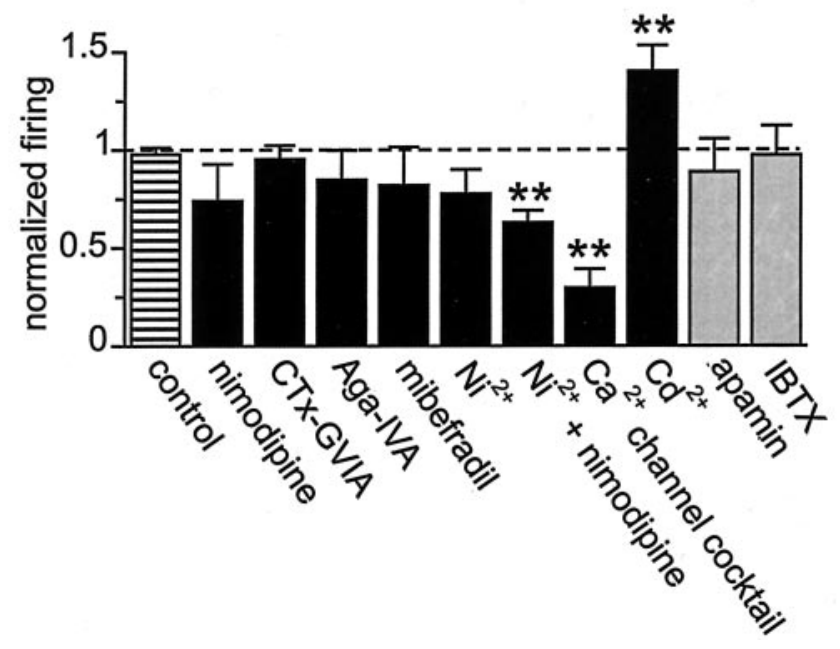

Figure 8. Effect on firing rate of $\mathrm{Ca}^{2+}$ channel and $\mathrm{K}_{\mathrm{Ca}}$ channel antagonists. $A$, Records ( 2 sec duration) of spontaneous firing in an $\mathrm{SCN}$ neuron under control conditions and after application of a mixture of $\mathrm{Ca}^{2+}$ channel blockers in the bath solution. The $\mathrm{Ca}^{2+}$ channel mixture contained nimodipine $(10 \mu \mathrm{M}), \omega$-CTX-GVIA $(3 \mu \mathrm{M}), \omega$-Aga-IVA $(200 \mathrm{nM})$, mibefradil ( $\left.500 \mathrm{~nm}\right)$, and $\mathrm{Ni}^{2+}$ $(30 \mu \mathrm{m}) . B$, Normalized firing rate in the presence of various channel blockers. Black bars represent results for $\mathrm{Ca}^{2+}$ channel antagonists, and gray bars represent results for $\mathrm{K}_{\mathrm{Ca}_{\mathrm{a}}}$ channel antagonists. All firing rates with antagonist were compared with a baseline firing rate in that neuron measured just before antagonist application. In control recordings, firing frequency did not significantly change over the first $15 \mathrm{~min}$ of whole-cell recording; at $15 \mathrm{~min}$, firing frequency was the same as that measured just after establishment of whole-cell recording (striped bar labeled control; $p>0.1 ; n=5$ ). The duration of experiments testing antagonist action on firing frequency was in all cases $<15 \mathrm{~min}$. Individual selective $\mathrm{Ca}^{2+}$ channel antagonists were applied at a dose equal to that used in the $\mathrm{Ca}^{2+}$ channel blocker mixture. Apamin and iberiotoxin were applied at $100 \mathrm{~nm}$. $\mathrm{Cd}^{2+}$ was applied at $30 \mu \mathrm{m}$. Firing rate experiments were performed in the presence of $30 \mu \mathrm{m}$ bicuculline methiodide. Sample size ranged from $n=$ $6-10$, except for experiments with $\mathrm{Cd}^{2+}$, for which $n=16$. Paired Student's $t$ test; ${ }^{* *} p<0.01$.

\section{Four types of high voltage-gated $\mathrm{Ca}^{2+}$ channels in SCN neurons}

On the basis of sensitivity to $\mathrm{Ca}^{2+}$ channel antagonists, our work shows that SCN neurons possess four principal components of high-voltage activated $\mathrm{Ca}^{2+}$ channel current: $\mathrm{L}-, \mathrm{N}-$, and $\mathrm{P} / \mathrm{Q}-$ currents, which had been previously identified in these neurons (Huang, 1993; Chen and van den Pol, 1998), and also R-type current. The precision in our measurement of relative current magnitude for the various $\mathrm{Ca}^{2+}$ channel subtypes was compromised by the imperfect selectivity of the specific channel antagonists, the incomplete block of individual $\mathrm{Ca}^{2+}$ channel subtypes, and the inability to voltage clamp distal processes of SCN neurons. Nonetheless, our pharmacological dissection of components of $\mathrm{Ca}^{2+}$ channel current yielded an estimate for the size of the L-type component that is similar to that reported for dissociated SCN neurons (Huang, 1993).

Our analysis revealed that R-type current was the largest current component in SCN neurons from slices. The majority of $\mathrm{R}$ current was blocked by low concentrations of $\mathrm{Ni}^{2+}$, although a proportion $\left(\sim 15 \%\right.$ of total $\mathrm{Ca}^{2+}$ channel current) remained that was insensitive to this concentration of $\mathrm{Ni}^{2+}$. The nonblocked fraction might represent $\mathrm{Ni}^{2+}$-insensitive $\mathrm{R}$ current (Schramm et al., 1999) or other $\mathrm{Ca}^{2+}$ channel components incompletely blocked at the antagonist doses used. Because SNX-482 did not block R current, $\alpha_{1 \mathrm{E}}$-based $\mathrm{Ca}^{2+}$ channels are not likely to support the $\mathrm{R}$ current of SCN neurons. R current identified here may correspond to the large component of $\mathrm{Ca}^{2+}$ current that was found in previous studies to be insensitive to the combination of nimodipine and $\omega$-CTx-GVIA (Huang, 1993).

\section{Coupling of $\mathrm{Ca}^{2+}$ channels to $\mathrm{K}_{\mathrm{Ca}}$ channels in SCN neurons}

In some neurons, tight coupling exists between specific $\mathrm{Ca}^{2+}$ channel subtypes and $\mathrm{K}_{\mathrm{Ca}}$ channel subtypes (Davies et al., 1996; Marrion and Tavalin, 1998; Borde et al., 2000; Martinez-Pinna et al., 2000), whereas in other neurons, multiple $\mathrm{Ca}^{2+}$ channel subtypes contribute to AHP activation (Williams et al., 1997; Pineda et al., 1998). In cluster I neurons of the SCN, both L- and R-type $\mathrm{Ca}^{2+}$ currents are involved in AHP activation. $\mathrm{N}$ and $\mathrm{T}$ channels make small contributions as well, and $\mathrm{P} / \mathrm{Q}$ channels appear not to contribute. That large-amplitude $\mathrm{N}$ and $\mathrm{P} / \mathrm{Q}$ currents contributed little or nothing to AHP activation suggests that $\mathrm{Ca}^{2+}$ channel subtypes are differentially distributed on SCN neurons, with L- and R-type channels located in closest proximity to $\mathrm{K}_{\mathrm{Ca}}$ channels.

\section{Physiological significance}

Neurons studied here were in the daytime phase of the circadian cycle, but we suggest that the relationship between firing frequency and AHP waveform may contribute to circadian control of firing frequency in SCN neurons. This proposed mechanism for circadian regulation of $\mathrm{K}_{\mathrm{Ca}}$ channel activity and the AHP might arise from circadian changes in the expression, splicing, post-translational modification, or regulation of specific $\mathrm{K}_{\mathrm{Ca}}$ channels.

In faster firing SCN neurons, a shortened interspike interval appears to rely in part on speeded decay of the $\mathrm{Cd}^{2+}$-sensitive component of the AHP, yet the $\mathrm{Cd}^{2+}$-sensitive component of the AHP was larger and action potentials were narrower in faster firing neurons, suggesting that peak $\mathrm{K}_{\mathrm{Ca}}$ channel activity is augmented in faster firing neurons. Thus in faster firing neurons the number of $\mathrm{K}_{\mathrm{Ca}}$ channels open at the peak of the AHP is increased, but the AHP terminates more rapidly. These two changes in the AHP might be accomplished in various ways. For example, the kinetics of $\mathrm{K}_{\mathrm{Ca}}$ channel gating might be speeded globally such that the maximal number of channels open simultaneously is increased (greater AHP magnitude) and yet the duration of the AHP is shortened. Alternatively, the increased magnitude of the AHP in faster firing neurons might be attributable to an increase in the number of $\mathrm{K}_{\mathrm{Ca}}$ channels available to open, and, in addition, SCN channels active in the range -50 to $-60 \mathrm{mV}$ and with a reversal potential positive to that of the AHP might exhibit increased activity (e.g., hyperpolarization-activated cation chan- 
Table 2. Effect of blockers of $\mathrm{Ca}^{2+}$ channels and of $\mathrm{K}_{\mathrm{Ca}}$ channels on membrane properties of cluster I SCN neurons

\begin{tabular}{|c|c|c|c|c|c|c|c|c|c|c|}
\hline & Control & $\mathrm{Cd}^{2+}$ & $\omega$-CTx-GVIA & $\omega$-Aga-IVA & Nimodipine & Mibefradil & $\mathrm{Ni}^{2+}$ & $I_{\mathrm{Ca}}$ mixture & Apamin & Iberiotoxin \\
\hline \multicolumn{11}{|l|}{ Number of neurons } \\
\hline$(n)$ & 60 & 10 & 6 & 6 & 6 & 6 & 6 & 8 & 6 & 6 \\
\hline $\begin{array}{l}\text { Interspike potential } \\
\quad(\mathrm{mV})\end{array}$ & $-41 \pm 0.8$ & $-41 \pm 1.6$ & $-37 \pm 1.9$ & $-38 \pm 1.4$ & $-39 \pm 2.7$ & $-40 \pm 1.3$ & $-37 \pm 2.1$ & $-38 \pm 2.6$ & $-41 \pm 1.5$ & $-37 \pm 3.1$ \\
\hline Spike amplitude & & & & & & & & & & \\
\hline$(\mathrm{mV})$ & $75 \pm 1.7$ & $60 \pm 4.7^{* *}$ & $69 \pm 1.8$ & $71 \pm 5.2$ & $75 \pm 4.5$ & $81 \pm 4.9$ & $78 \pm 5.1$ & $72 \pm 4.3$ & $80 \pm 3.5$ & $73 \pm 6.2$ \\
\hline Spike width (msec) & $2.4 \pm 0.1$ & $4.2 \pm 0.5^{* *}$ & $3.1 \pm 0.2^{*}$ & $3.0 \pm 0.3$ & $2.6 \pm 0.3$ & $2.3 \pm 0.2$ & $2.4 \pm 0.2$ & $3.6 \pm 0.4^{* *}$ & $2.4 \pm 0.2$ & $4.0 \pm 0.4^{* *}$ \\
\hline
\end{tabular}

Membrane properties were measured as described in Table 1. Concentrations of blockers used are as given in Materials and Methods. I Ca $_{\text {a }}$ blocker mixture represents the combination of $10 \mu \mathrm{M} \mathrm{nimodipine,} 3 \mu \mathrm{M} \omega$-CTx-GVIA, $200 \mathrm{~nm}$ $\omega$-Aga-IVA, $30 \mu \mathrm{M} \mathrm{Ni}^{2+}$, and $500 \mathrm{~nm}$ mibefradil. ${ }^{*} p<0.05$, ${ }^{* *} p<0.01$, compared with control.

nels (Akasu et al., 1993) or $\mathrm{Na}^{+}$channels (Pennartz et al., 1997). Increased activity of these latter kinds of channels might mask the full duration of $\mathrm{K}_{\mathrm{Ca}}$ channel activity and terminate the AHP more rapidly. The fact that faster firing neurons did not hyperpolarize more than slower firing neurons, although the net size of the $\mathrm{Cd}^{2+}$-subtracted AHP was greater in faster neurons, is consistent with the idea that these channels might compensate for the hyperpolarizing influence of $\mathrm{K}_{\mathrm{Ca}}$ channels. In this case, circadian dependence on the activity of these channels, as well as of $\mathrm{K}_{\mathrm{Ca}}$ channels, may be involved in determining the duration of the AHP and the frequency of firing.

In spontaneously firing SCN neurons, full suppression of the $\mathrm{Ca}^{2+}$-dependent AHP by application of $\mathrm{Cd}^{2+}$ increased firing rate (Fig. $8 \mathrm{~B}$ ), whereas partial suppression of the AHP by mixtures of specific $\mathrm{Ca}^{2+}$ channel blockers had the opposite effect. This unexpected contrast could arise if voltage-gated $\mathrm{Ca}^{2+}$ channels participate both in bringing neurons above firing threshold and in triggering the AHP. In this scenario, the net effect on firing rate of block of $\mathrm{Ca}^{2+}$ channels would reflect the balance between a slowed trajectory through firing threshold (decreased firing rate) versus a reduced AHP duration (increased rate). In the case of $\mathrm{Cd}^{2+}$ block, we speculate that the effect of full suppression of the AHP dominates over the slowed trajectory through threshold, so that neurons fire faster. With the $\mathrm{Ca}^{2+}$ channel blocker mixtures, we speculate that slowed trajectory through threshold dominates over the effect of partial suppression of the AHP, resulting in a net decrease in neuronal firing.

The molecular mechanism of the frequency-dependent change in AHP waveform appears to be based in part on $\mathrm{K}_{\mathrm{Ca}}$ channels that are insensitive to either apamin or iberiotoxin, because application of these specific antagonists did not alter firing frequency. Additionally, there was no correlation between parameters of the iberiotoxin-sensitive component of the AHP and firing rate. We conclude that other $\mathrm{K}_{\mathrm{Ca}}$ channel types, perhaps iberiotoxin-insensitive $\mathrm{BK}_{\mathrm{Ca}}$ channels (Meera et al., 2000) or $\mathrm{IK}_{\mathrm{Ca}}$ channels, are modulated in a manner that diurnally alters the firing rate of SCN neurons. For these $\mathrm{K}_{\mathrm{Ca}}$ channels, circadian modulation might occur via second messenger-mediated modification of channel function, via changes in the coupling of $\mathrm{Ca}^{2+}$ entry (Pennartz et al., 2002) to channel activation, or by altered expression of channels or associated regulatory proteins. A notable recent finding regarding this latter point is that transcription of $\mathrm{Slob}$, which encodes $\mathrm{a} \mathrm{Ca}^{2+}$-binding protein that interacts with and regulates the activity of the Slo $\mathrm{K}_{\mathrm{Ca}}$ channel (Schopperle et al., 1998), is under circadian control in Drosophila (Claridge-Chang et al., 2001; McDonald and Rosbash, 2001). More recently, expression of the mammalian ortholog of the BK-type Slo channel, Kcnma1, has also been found to be under circadian control (Panda et al., 2002). The convergence on $\mathrm{K}_{\mathrm{Ca}}$ channels of molecular and electrophysiological approaches underscores the likely importance of these channels in the mechanism of circadian firing of SCN neurons.

\section{References}

Aizenman CD, Linden DJ (1999) Regulation of the rebound depolarization and spontaneous firing patterns of deep nuclear neurons in slices of rat cerebellum. J Neurophysiol 82:1697-1709.

Akasu T, Shoji S, Hasuo H (1993) Inward rectifier and low-threshold calcium currents contribute to the spontaneous firing mechanism in neurons of the rat suprachiasmatic nucleus. Pflügers Arch 425:109-116.

Akita T, Kuba K (2000) Functional triads consisting of ryanodine receptors, $\mathrm{Ca}^{2+}$ channels and $\mathrm{Ca}^{2+}$-activated $\mathrm{K}^{+}$channels in bullfrog sympathetic neurons: plastic modulation of action potential. J Gen Physiol 116:697-720.

Anderson CS, MacKinnon R, Smith C, Miller C (1988) Charybdotoxin block of single $\mathrm{Ca}^{2+}$-activated $\mathrm{K}^{+}$channels. Effects of channel gating, voltage, and ionic strength. J Gen Physiol 91:317-333.

Barrett EF, Barrett JN (1976) Separation of two voltage-sensitive potassium currents, and demonstration of a tetrodotoxin-resistant calcium current in frog motoneurones. J Physiol (Lond) 255:737-774.

Bekkers JM (2000) Properties of voltage-gated potassium currents in nucleated patches from large layer 5 cortical pyramidal neurons of the rat. J Physiol (Lond) 525:593-609.

Bevan MD, Wilson CJ (1999) Mechanisms underlying spontaneous oscillation and rhythmic firing in rat subthalamic neurons. J Neurosci 19:7617-7628.

Bezprozvanny I, Tsien RW (1995) Voltage-dependent blockade of diverse types of voltage-gated $\mathrm{Ca}^{2+}$ channels expressed in Xenopus oocytes by the $\mathrm{Ca}^{2+}$ channel antagonist mibefradil (Ro 40-5967). Mol Pharmacol 48:540-549.

Blatz A, Magleby KL (1986) Single apamin-blocked Ca-activated $\mathrm{K}^{+}$channels of small conductance in cultured rat muscle cells. Nature 323:718-720.

Boland LM, Morril JA, Bean BP (1994) $\omega$-conotoxin block of N-type calcium channels in frog and rat sympathetic neurons. J Neurosci 14:5011-5027.

Borde M, Bonansco C, Fernandez de Sevilla D, Le Ray D, Bruno W (2000) Voltage-clamp analysis of the potentiation of the slow $\mathrm{Ca}^{2+}$-activated $\mathrm{K}^{+}$ current in hippocampal pyramidal neurons. Hippocampus 10:198-206.

Candia S, Garcia ML, Latorre R (1992) Mode of action of iberiotoxin, a potent blocker of the large conductance $\mathrm{Ca}^{2+}$-activated $\mathrm{K}^{+}$channel. Biophys J 63:583-590.

Chen G, van den Pol AN (1998) Presynaptic GABA $A_{B}$ autoreceptor modulation of P/Q-type calcium channels and GABA release in rat suprachiasmatic nucleus neurons. J Neurosci 18:1913-1922.

Claridge-Chang A, Wijnen H, Naef F, Boothroyd C, Rajewsky N, Young MW (2001) Circadian regulation of gene expression systems in the Drosophila head. Neuron 32:657-671.

Davies PJ, Ireland DR, McLachlan EM (1996) Sources of $\mathrm{Ca}^{2+}$ for different $\mathrm{Ca}^{2+}$-activated $\mathrm{K}^{+}$conductances in neurones of the rat superior cervical ganglion. J Physiol (Lond) 494:353-366.

Ding JM, Buchanan GF, Tischkau SA, Chen D, Kuriashkina L, Faiman LE, Alster JM, McPherson PS, Campbell KP, Gillette MU (1998) A neuronal ryanodine receptor mediates light-induced phase delays of the circadian clock. Nature 394:381-384.

Dunlap JC (1999) Molecular bases for circadian clocks. Cell 96:271-290.

Earnest DJ, Digiorgio SM, Sladek CD (1991) Effects of tetrodotoxin on the 
circadian pacemaker mechanism in suprachiasmatic explants in vitro. Brain Res Bull 26:677-682.

Foehring RC, Mermelstein PG, Song WJ, Ulrich S, Surmeier DJ (2000) Unique properties of R-type calcium currents in neocortical and neostriatal neurons. J Neurophysiol 84:2225-2236.

Galvez A, Gimenez-Gallego G, Reuben JP, Roy-Contancin L, Feigenbaum P, Kaczorowski GJ, Garcia ML (1990) Purification and characterization of a unique, potent, peptidyl probe for the high conductance calciumactivated potassium channel from venom of the scorpion Buthus tamulus. J Biol Chem 265:11083-11090.

Gandolfo G, Schweitz H, Lazdunski M, Gottesmann C (1996) Sleep cycle disturbances induced by apamin, a selective blocker of $\mathrm{Ca}^{2+}$-activated $\mathrm{K}^{+}$channels. Brain Res 736:344-347.

Gillette MU (1991) SCN electrophysiology in vitro: rhythmic activity and endogenous clock properties. In: Suprachiasmatic nucleus: the mind's clock (Klein DC, Moore RY, Reppert SM, eds), pp 125-143. New York: Oxford UP.

Gribkoff VK, Starrett JE, Dworetzky SI (1997) The pharmacology and molecular biology of large-conductance calcium-activated (BK) potassium channels. Adv Pharmacol 37:319-348.

Huang RC (1993) Sodium and calcium currents in acutely dissociated neurons from rat suprachiasmatic nucleus. J Neurophysiol 70:1692-1703.

Hughes M, Romey G, Duval D, Vincent J, Lazdunski M (1982) Apamin as a selective blocker of the calcium-dependent potassium channel in neuroblastoma cells. Voltage-clamp and biochemical characterization of the toxin receptor. Proc Natl Acad Sci USA 79:1308-1312.

Inouye S-IT, Kawamura H (1979) Persistence of circadian rhythmicity in a mammalian hypothalamic "island" containing the suprachiasmatic nucleus. Proc Natl Acad Sci USA 76:5962-5966.

Jagota A, de la Iglesia HO, Schwartz WJ (2000) Morning and evening circadian oscillations in the suprachiasmatic nucleus in vitro. Nat Neurosci 3:372-376.

Jiang ZG, Nelson CS, Allen CN (1995) Melatonin activates an outward current and inhibits $I_{h}$ in rat suprachiasmatic nucleus neurons. Brain Res 687:125-132.

Kaczorowski GJ, Garcia ML (1999) Pharmacology of voltage-gated and calcium-activated potassium channels. Curr Opin Chem Biol 3:448-458.

Khawaled R, Bruening-Wright A, Adelman JP, Maylie J (1999) Bicuculline block of small-conductance calcium-activated potassium channels. Pflügers Arch 438:314-321.

Klein DC, Moore RY, Reppert SM (1991) Suprachiasmatic nucleus: the mind's clock. New York: Oxford UP.

Kohler M, Hirschberg B, Bond CT, Kinzie JM, Marrion NV, Maylie J, Adelman JP (1996) Small-conductance, calcium-activated potassium channels from mammalian brain. Science 273:1709-1714.

Lee JH, Gomora JC, Cribbs LL, Perez-Reyes E (1999) Nickel block of three cloned T-type calcium channels: low concentrations selectively block $\alpha_{1 \mathrm{H}}$. Biophys J 77:3034-3042.

Lee SC, Choi S, Lee T, Kim HL, Chin H, Shin HS (2002) Molecular basis of R-type calcium channel in central amygdala neurons of the mouse. Proc Natl Acad Sci USA 99:3276-3281.

Madison DV, Nicoll RA (1982) Noradrenaline blocks accommodation of pyramidal cell discharge in the hippocampus. Nature 299:636-638.

Madison DV, Nicoll RA (1986) Actions of noradrenaline recorded intracellularly in rat hippocampal CA1 pyramidal neurones, in vitro. J Physiol (Lond) 372:221-244.

Marchetti C, Amico C, Usai C (1995) Functional characterization of the effects of nimodipine on the calcium current in rat cerebellar granule cells. J Neurophysiol 73:1169-1180.

Marrion NV, Tavalin SJ (1998) Selective activation of $\mathrm{Ca}^{2+}$-activated $\mathrm{K}^{+}$ channels by co-localized $\mathrm{Ca}^{2+}$ channels in hippocampal neurons. Nature 395:900-905.

Martin RL, Lee JH, Cribbs LL, Perez-Reyes E, Hanck DA (2000) Mibefradil block of cloned T-type calcium channels. J Pharmacol Exp Ther 295:302-308.

Martinez-Pinna J, McLachlan EM, Gallego R (2000) Distinct mechanisms for activation of $\mathrm{Cl}^{-}$and $\mathrm{K}^{+}$currents by $\mathrm{Ca}^{2+}$ from different sources in mouse sympathetic neurones. J Physiol (Lond) 527:249-264.

McDonald MJ, Rosbash M (2001) Microarray analysis and organization of circadian gene expression in Drosophila. Cell 107:567-578.

McDonough SI, Bean BP (1998) Mibefradil inhibition of T-type calcium channels in cerebellar Purkinje neurons. Mol Pharmacol 54:1080-1087.
Meera P, Wallner M, Toro L (2000) A neuronal beta subunit (KCNMB4) makes the large conductance, voltage- and $\mathrm{Ca}^{2+}$-activated $\mathrm{K}^{+}$channel resistant to charybdotoxin and iberiotoxin. Proc Natl Acad Sci USA 97:5562-5567.

Mintz IM, Venema VJ, Swiderek KM, Lee TD, Bean BP, Adams ME (1992) P-type calcium channels blocked by the spider toxin $\omega$-Aga-IVA. Nature 355:827-829.

Moore RY, Eichler VB (1972) Loss of circadian adrenal corticosterone rhythm following suprachiasmatic lesions in the rat. Brain Res 42:201-206.

Neher E (1992) Correction for liquid junction potentials in patch clamp experiments. In: Methods in enzymology (Rudy B, Iverson LE, eds), pp 123-131. San Diego: Academic.

Newcomb R, Szoke B, Palma A, Wang G, Chen XH, Hopkins W, Cong R, Miller J, Urge L, Tarczy-Hornoch K, Loo JA, Dooley DJ, Nadasdi L, Tsien RW, Lemos J, Miljanich G (1998) Selective peptide antagonist of the class E calcium channel from the venom of the tarantula Hysterocrates gigas. Biochemistry 37:15353-15362.

Newman GC, Hospod FE, Patlak CS, Moore RY (1992) Analysis of in vitro glucose utilization in a circadian pacemaker model. J Neurosci 12:2015-2021.

N'Gouemo P, Rittenhouse AR (2000) Biophysical and pharmacological characterization of voltage-sensitive calcium currents in neonatal rat inferior colliculus neurons. Neuroscience 96:753-765.

Panda S, Antoch MP, Miller BH, Su AI, Schook AB, Straume M, Schultz PG, Kay SA, Takahashi JS, Hogenesch JB (2002) Coordinated transcription of key pathways in the mouse by the circadian clock. Cell 109:307-320.

Pedarzani P, Storm JF (1995) Dopamine modulates the slow $\mathrm{Ca}^{2+}$. activated $\mathrm{K}^{+}$current $I_{A H P}$ via cyclic AMP-dependent protein kinase in hippocampal neurons. J Neurophysiol 74:2749-2753.

Pennartz CMA, Bierlaagh MA, Geurtsen AMS (1997) Cellular mechanisms underlying spontaneous firing in rat suprachiasmatic nucleus: involvement of a slowly inactivating component of sodium current. J Neurophysiol 78:1811-1825.

Pennartz CMA, de Jeu MTG, Geurtsen AMS, Sluiter AA, Hermes MLHJ (1998) Electrophysiological and morphological heterogeneity of neurons in slices of rat suprachiasmatic nucleus. J Physiol (Lond) 506:775-793.

Pennartz CMA, de Jeu MTG, Bos NP, Schaap J, Geurtsen AMS (2002) Diurnal modulation of pacemaker potentials and calcium current in the mammalian circadian clock. Nature 416:286-290.

Pineda JC, Waters RS, Foehring RC (1998) Specificity in the interaction of HVA Ca ${ }^{2+}$ channel types with $\mathrm{Ca}^{2+}$-dependent AHPs and firing behavior in neocortical pyramidal neurons. J Neurophysiol 79:2522-2534.

Prosser RA, Heller HC, Miller JD (1994) Serotonergic phase advances of the mammalian circadian clock involve protein kinase A and $\mathrm{K}^{+}$channel opening. Brain Res 644:67-73.

Randall AD, Tsien RW (1995) Pharmacological dissection of multiple types of $\mathrm{Ca}^{2+}$ channel currents in rat cerebellar granule neurons. J Neurosci 15:2995-3012.

Reppert SM, Weaver DR (2001) Molecular analysis of mammalian circadian rhythms. Annu Rev Physiol 63:647-676.

Sah P (1996) $\mathrm{Ca}^{2+}$-activated $\mathrm{K}^{+}$currents in neurones: types, physiological roles and modulation. Trends Neurosci 19:150-154.

Sah P, Davies P (2000) Calcium-activated potassium currents in mammalian neurons. Clin Exp Pharmacol Physiol 27:657-663.

Sah P, Faber ES (2002) Channels underlying neuronal calcium-activated potassium currents. Prog Neurobiol 66:345-353.

Schopperle WM, Holmqvist MH, Zhou Y, Wang J, Wang Z, Griffith LC, Keselman I, Kusinitz F, Dagan D, Levitan IB (1998) Slob, a novel protein that interacts with the Slowpoke calcium-dependent potassium channel. J Neurosci 20:565-573.

Schramm M, Vajna R, Preverzev A, Tottene A, Klockner U, Pietrobon D, Hescheler J, Schneider T (1999) Isoforms of $\alpha_{1 \mathrm{E}}$ voltage-gated calcium channels in rat cerebellar granule cells: detection of major calcium channel $\alpha_{1}$ transcripts by reverse transcription-polymerase chain reaction. Neuroscience 92:565-575.

Schwartz WJ (1991) Further evaluation of the tetrodotoxin-resistant circadian pacemaker in the suprachiasmatic nuclei. J Biol Rhythms 6:149-158.

Schwartz WJ, Gross RA, Morton MT (1987) The suprachiasmatic nuclei contain a tetrodotoxin-resistant circadian pacemaker. Proc Natl Acad Sci USA 84:1694-1698. 
Stocker M, Pedarzani P (2000) Differential distribution of three $\mathrm{Ca}^{2+}$ activated $\mathrm{K}^{+}$channel subunits, SK1, SK2, and SK3, in the adult rat central nervous system. Mol Cell Neurosci 15:476-493.

Strecker GJ, Wuarin JP, Dudek FE (1997) GABA $_{\mathrm{A}}$-mediated local synaptic pathways connect neurons in the rat suprachiasmatic nucleus. J Neurophysiol 78:2217-2220.

Sutko JL, Ito K, Kenyon JL (1985) Ryanodine: a modifier of sarcoplasmic reticulum calcium release in striated muscle. Fed Proc 44:2984-2988.

Talley EM, Cribbs LL, Lee JH, Daud A, Perez-Reyes E, Bayliss DA (1999) Differential distribution of three members of a gene family encoding low voltage-activated (T-type) calcium channels. J Neurosci 19:1895-1911.

Tottene A, Moretti A, Pietrobon D (1996) Functional diversity of P-type and R-type calcium channels in rat cerebellar neurons. J Neurosci 16:6353-6363.

Tottene A, Volsen S, Pietrobon D (2000) $\alpha_{1 \mathrm{E}}$ subunits form the pore of three cerebellar R-type calcium channels with different pharmacological and permeation properties. J Neurosci 20:171-178.

Vergara C, Latorre R, Marrion NV, Adelman JP (1998) Calcium-activated potassium channels. Curr Opin Neurobiol 8:321-329.

Vilchis C, Bargas J, Ayala GX, Galvan E, Galarraga E (2000) $\mathrm{Ca}^{2+}$ channels that activate $\mathrm{Ca}^{2+-}$ dependent $\mathrm{K}^{+}$currents in neostriatal neurons. Neuroscience 95:745-752.

Wang G, Dayanithi G, Newcomb R, Lemos JR (1999) An R-type Ca ${ }^{2+}$ cur- rent in neurohypophysial terminals preferentially regulates oxytocin secretion. J Neurosci 19:9235-9241.

Welsh DK, Logothetis DE, Meister M, Reppert SM (1995) Individual neurons dissociated from rat suprachiasmatic nucleus express independently phased circadian firing rhythms. Neuron 14:697-706.

Williams S, Serafin M, Mühlethaler M, Bernheim L (1997) Distinct contributions of high- and low-voltage-activated calcium currents to afterhyperpolarizations in cholinergic nucleus basalis neurons of the guinea pig. J Neurosci 17:7307-7315.

Xu W, Lipscombe D (2001) Neuronal Ca(V)1.3 $\alpha$ (1) L-type channels activate at relatively hyperpolarized membrane potentials and are incompletely inhibited by dihydropyridines. J Neurosci 21:5944-5951.

Yarom Y, Sugimori M, Llinas R (1985) Ionic currents and firing patterns of mammalian vagal motoneurons in vitro. Neuroscience 16:719-737.

Zamponi GW, Bourinet E, Snutch TP (1996) Nickel block of a family of neuronal calcium channels: subtype- and subunit-dependent action at multiple sites. J Membr Biol 151:77-90.

Zhang JF, Randall AD, Ellinor PT, Horne WA, Sather WA, Tanabe T, Schwarz TL, Tsien RW (1993) Distinctive pharmacology and kinetics of cloned neuronal $\mathrm{Ca}^{2+}$ channels and their possible counterparts in mammalian CNS neurons. Neuropharmacology 32:1075-1088. 